\title{
The Fellowship of Privileged Scaffolds-One Structure to Inhibit Them All
}

\author{
Marcin Skoreński and Marcin Sieńczyk * (B)
}

Department of Organic and Medicinal Chemistry, Faculty of Chemistry, Wroclaw University of Science and Technology, Wybrzeze Wyspianskiego 27, 50-370 Wrocław, Poland; marcin.skorenski@pwr.edu.pl

* Correspondence: marcin.sienczyk@pwr.edu.pl

check for updates

Citation: Skoreński, M.; Sieńczyk, M. The Fellowship of Privileged Scaffolds-One Structure to Inhibit Them All. Pharmaceuticals 2021, 14, 1164. https://doi.org/10.3390/ ph14111164

Academic Editor: Urszula K. Komarnicka

Received: 11 October 2021 Accepted: 11 November 2021 Published: 16 November 2021

Publisher's Note: MDPI stays neutral with regard to jurisdictional claims in published maps and institutional affiliations.

Copyright: (C) 2021 by the authors. Licensee MDPI, Basel, Switzerland. This article is an open access article distributed under the terms and conditions of the Creative Commons Attribution (CC BY) license (https:/ / creativecommons.org/licenses/by/ $4.0 /)$.
Abstract: Over the past few years, the application of privileged structure has emerged as a powerful approach to the discovery of new biologically active molecules. Privileged structures are molecular scaffolds with binding properties to the range of different biological targets. Moreover, privileged structures typically exhibit good drug-like properties, thus assuring more drug-like properties of modified compound. Our main objective is to discuss the privileged structures used for the development of antiviral agents.

Keywords: privileged structures; enzyme inhibitors; antivirals

\section{Introduction}

The term 'privileged structure' was first coined in 1988 by Evans et al., who used it to describe repeating structural motifs as useful templates for discovering new biological active molecules [1]. During their early studies, they had noticed that particular chemical structures are able to bind with equal affinity to more than one type of receptor. Subsequently, the approach where sensible modifications of privileged structures could lead to the proposal of new potent agonists or antagonists of the receptors. Since then, the number of studies in the field of medicinal chemistry that employed this methodology has been systematically growing, reaching now 6285 records according to Web of Science (Figure 1).

In the context of the 'privileged structure' term, it is worth addressing the issue of pan-assay interference compounds (PAINS). These molecules bind to the target but their activity does not depend on a specific, drug-like interaction between molecule and protein. Thus, there is a risk of mistake identification of chemical scaffold as a privileged structure while it is PAINS [2-6]. Currently, 400 structural classes of PAINS have been identified, but the most frequent PAINS encompasses 16 categories [7,8]. In some cases, PAINS are able to react with protein in the specific, drug-like mode and could serve as a starting template for structure optimisation. To exclude incorrect hit identification, researchers should check the literature carefully and look into the similarities between reported PAINS. It would be beneficial to conduct at least two types of activity assays to identify hits [8].

Despite possible pitfalls associated with PAINS, an increasing number of new inhibitors targeting diverse molecular targets and the availability of improved data analysis tools prompt a conclusion that the privileged structure-based approach will be applied in a larger number of studies. Here, we discuss privileged structures which were identified as highly useful in the development of novel antiviral agents acting at various molecular levels. We also describe new scaffolds which have not been identified in scientific literature so far. We have only dealt with scientific reports published after 2009. 


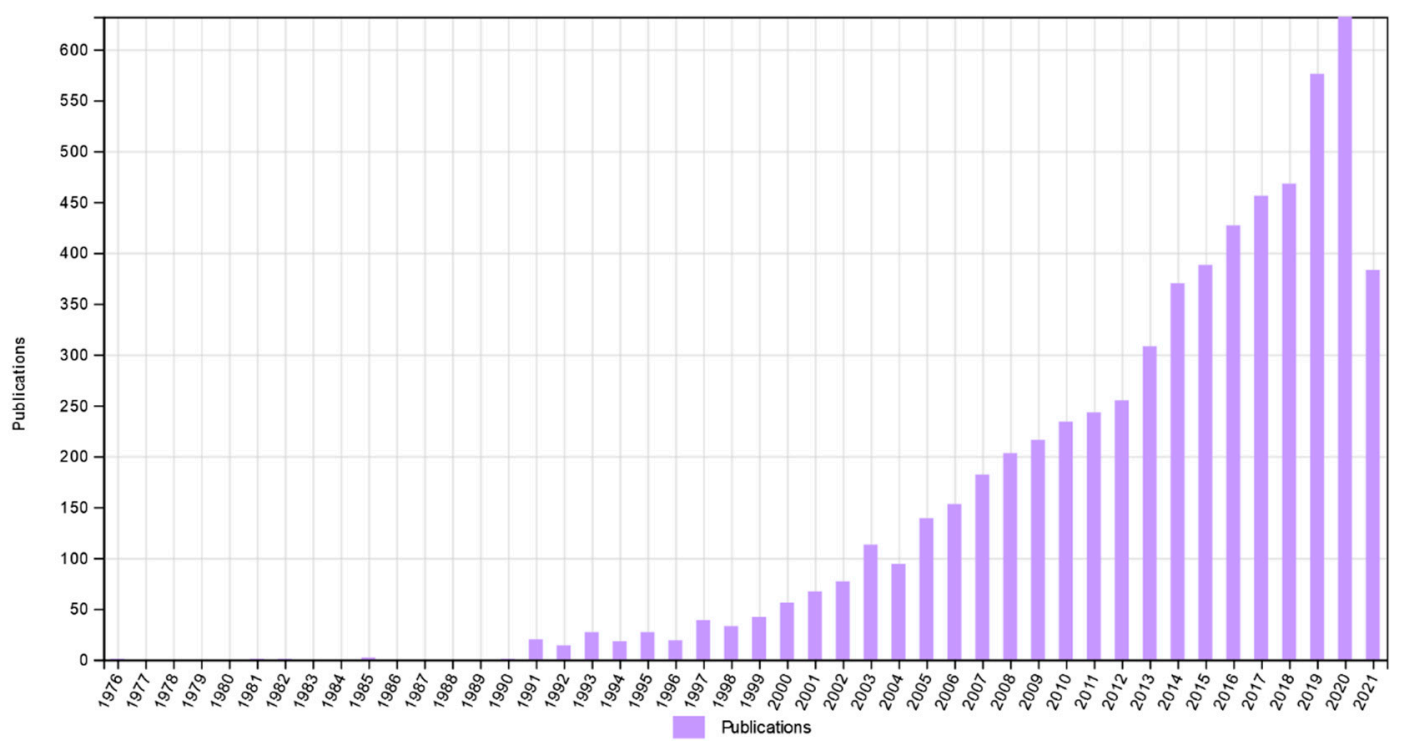

Figure 1. Numbers of publications over time when searching "privileged structure" as topic term (according to Web of Science, date: 27 September 2021).

\section{Diaryl Ether (DE)}

The diaryl ether (DE) motif is present in many drugs which have already been approved by the FDA (Food and Drug Administration). Roxadustad, Ibrutinib and Sorafenib are only three representatives thereof [9-11]. This structural scaffold bearing two aromatic rings and flexible oxygen bridge displays high hydrophobicity, which is why DE improves cell membrane penetration of the final molecule and its solubility in lipids. An incorporation of DE into the target biologically active compound ensures good metabolic stability of the new molecule [12]. Recently, Tao Chen et al. and Kini et al. published excellent, comprehensive reviews about the diaryl ether scaffold present in various drugs and agrochemicals $[13,14]$. Here, we would like to focus on antiviral agents containing DE moiety in their structure.

\subsection{Anti-HIV Agents}

Inhibitors targeting HIV-1 reverse transcriptase (RT) are important components of highly active antiretroviral therapy (HAART). The first FDA-approved non-nucleoside inhibitor of HIV-1 reverse transcriptase (NNRTI) was Nevirapine [15]. The potency of this inhibitor's action is limited in case of single-point mutation (e.g., K103N, Y181C, G190A) variants of HIV-1 reverse transcriptase, which is the reason why extensive research was done to find active, mutation-resistant inhibitors [16]. From six of the FDA-approved inhibitors, Etravirine (TMC125; 1) and Doravirine (MK-1439; 2 ) contain DE with a modified benzene ring within their structure (Figure 2).

Currently, numerous studies are focused on the design and synthesis of HIV reverse transcriptase inhibitors containing a DE motif. Such a biarylether class of inhibitors binds the phenol ring of enzyme Y188 residue to the enzyme through $\pi$-stacking of the terminal aryl ring of the inhibitor [17]. In 2011, Bollini et al. presented catechol diether containing uracil and cyanovinylphenyl groups in its structure. Among inhibitors of this series, compound 3 showed extremely high potency of action with $\mathrm{EC}_{50}$ and $\mathrm{CC}_{50}$ values of $55 \mathrm{pM}$ and $10 \mu \mathrm{M}$, respectively. The subsequent molecular modelling approach revealed the presence of possible interactions between the phenyl ring of DE and tyrosine side chain 188 [18], which was further confirmed by solving the X-ray crystal structure of the enzyme-inhibitor complex [19]. The continuation of these studies led to the discovery of two inhibitors 4 and $\mathbf{5}$ which displayed improved potency of action against mutant variants of RT, where compound 4 showed the $\mathrm{EC}_{50}$ values of $46 \mathrm{nM}$ and $16 \mathrm{nM}$ against $\mathrm{Y} 181 \mathrm{C}$ and K103N/Y181C, respectively [20]. Similarly, inhibitor 5 showed $\mathrm{EC}_{50}=16 \mathrm{nM}$ and 
$85 \mathrm{nM}$ toward the same RT mutants. Compound 4 was also more soluble than all examined inhibitors of this class such as Rilpivirine, Nevirapine or Efavirenz, which improved the bioavailability of obtained molecule.

In the same year, Jorgensen et al. developed a series of non-nucleoside reverse transcriptase inhibitors with the structure based on the DE scaffold. From the library of synthesized compounds, inhibitor 6 was most active, showing $\mathrm{EC}_{50}$ values of $2.5 \mathrm{nM}$ and $4.9 \mathrm{nM}$ against wild type and emerging mutant Y181C of HIV reverse transcriptase, respectively [21].

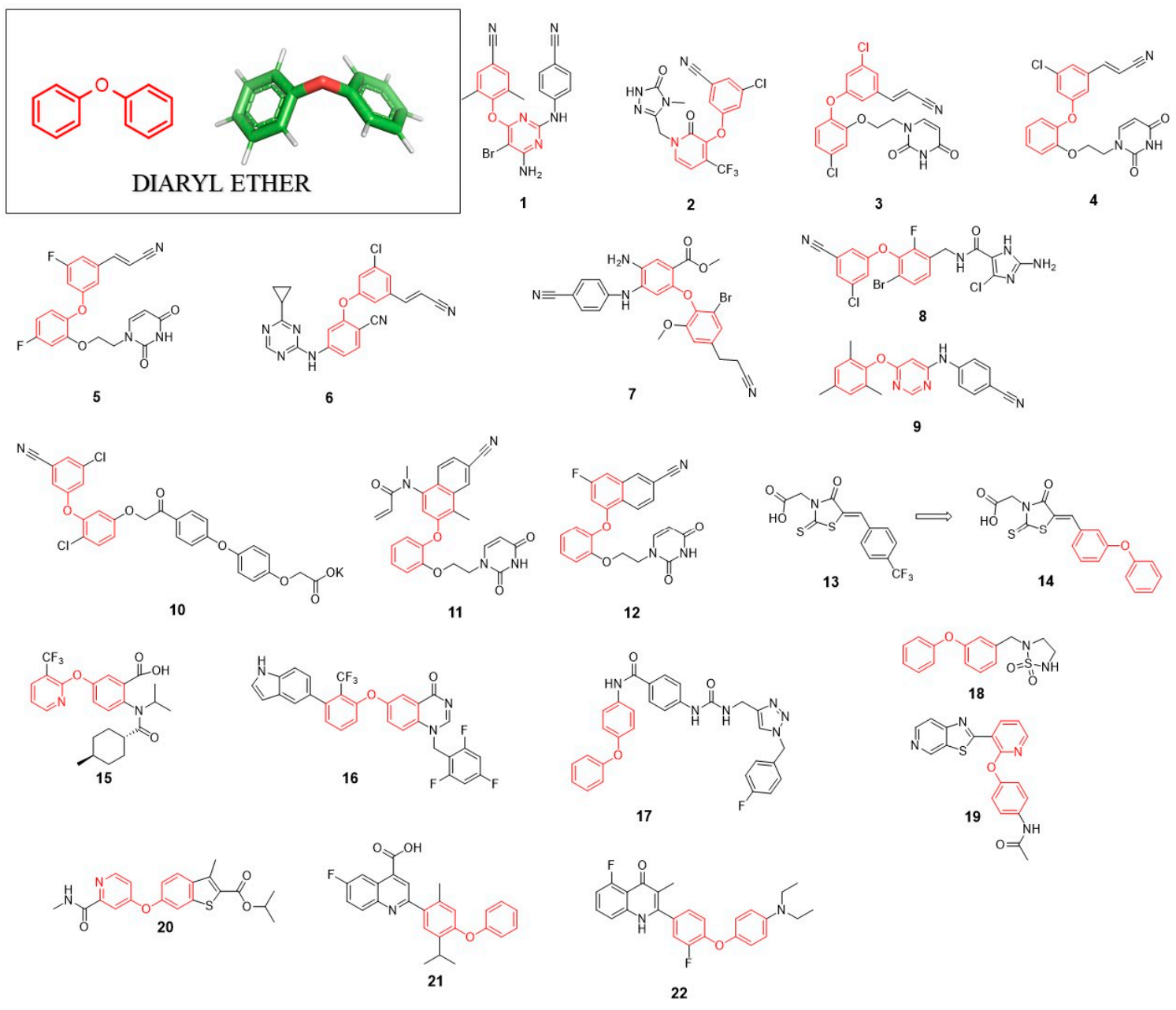

Figure 2. Antivirals with diaryl ether (DE) structure.

In a series of articles published by the Lan Xie research group, diarylaniline was used as a core structure for the development of new HIV-1 non-nucleoside reverse transcriptase inhibitors in which the DE moiety interact with so-called the "western wing" binding pocket of reverse transcriptase [22-25]. The extensive optimization studies led to the generation of highly potent molecules active against wild type (WT) and E138K mutant reverse transcriptase. Compound 7 displayed low nanomolar $\mathrm{EC}_{50}$ values of $5.19 \mathrm{nM}$ and $9.98 \mathrm{nM}$ against WT and E138K mutant, respectively [25].

In 2012, the Andrew Peat group developed extremely potent inhibitors of HIV-1 reverse transcriptase [26]. Compound 8 showed $\mathrm{EC}_{50}<1 \mathrm{nM}$ against enzyme wild type as well as against K103N and Y181C mutants. Only a slight activity loss was noticed against Y188L mutant $\left(\mathrm{EC}_{50}=0.5 \mathrm{nM}\right)$ as compared to the activity against WT. The structure of 8 in addition to the DE motif contains the substituted imidazole ring responsible for extensive $\mathrm{H}$-bond network formation with reverse transcriptase which are of high importance in blocking the activity of Y188L mutant. 
In 2012, Ribone et al. presented a series of novel 4,6-diarylpyrimidines and diarylbenzenes as inhibitors of HIV-1 [27]. Among all synthesized derivatives, 9 was the most active against the WT HIV-1 $\left(\mathrm{EC}_{50}=0.049 \mu \mathrm{M}\right)$. However, no activity was noticed against the double HIV-1 mutant (K103N + Y181C). Subsequent molecular modelling evaluation revealed that methyl substitutions in the ortho positions of the DE ring introduce steric hindrance responsible for beneficial spatial arrangement, which maximizes the $\pi-\pi$ stacking interaction with Y181, Y188 and W229 of HIV reverse transcriptase.

Five years later, Fraczek et al. presented a series of novel diaryl ethers with phenacyl moiety as inhibitors of HIV reverse transcriptase [28]. The designed compounds contain a polar group which improves inhibitors solubility. The most promising compound from these studies, 10, showed the $\mathrm{IC}_{50}$ value of $0.36 \mu \mathrm{M}$ toward HIV reverse transcriptase. Although the authors claimed that $\mathbf{1 0}$ showed antiviral activity, unfortunately, no $\mathrm{EC}_{50}$ value was provided.

In order to overcome the loss of inhibitors activity toward the Y181C mutation of reverse transcriptase, Chan et al. presented new compounds containing acryl amide warhead able to form a covalent bond with C181 [29]. The most potent inhibitor 11 showed an irreversible mode of action with the $\mathrm{k}_{2} / \mathrm{K}_{\mathrm{i}}$ of $195,000 \mathrm{M}^{-1} \mathrm{~s}^{-1}$. Further studies of antiviral activity using HIV-1-infected cells showed that 5 displayed the $\mathrm{EC}_{50}$ values of $0.56 \mu \mathrm{M}$ and $0.5 \mu \mathrm{M}$ against WT and K103N/Y181C, respectively. Crystallographic data indicate that 11 containing the methylacrylamide group forms a covalent bond with the thiol group of HIV reverse transcriptase $\mathrm{C} 181$. Although the $\mathrm{EC}_{50}$ value of $\mathbf{1 1}$ is not impressive when compared to the already known reverse transcriptase inhibitors, the concept of irreversible inhibition of HIV reverse transcriptase seems to be an attractive alternative for a further development of novel antiviral drugs. The application of the inhibitors of the irreversible type is especially beneficial when applied against drug-resistant mutants.

Recently, Kudalkar et al. have identified an effective HIV-1 NNRTI: 12 was very potent with an $\mathrm{IC}_{50}$ value of $=4.8 \mathrm{nM}$ and exhibited very potent antiviral activity in a cellbased assay displaying an $\mathrm{EC}_{50}$ value of $1.1 \mathrm{nM}$ with a simultaneous lack of cytotoxicity $\left(\mathrm{CC}_{50}>100 \mu \mathrm{M}\right)$ [14]. The authors also prepared poly(lactide-coglycolide)-based particles as long-acting nanoformulation of $\mathbf{1 2}$. One of the aryl groups from DE moiety present in this compound was replaced by the naphthyl ring. As crystallographic data show, this naphtyl ring interacts with the enzyme via van der Waals interactions with P95, L100, V108, Y188, W229, F227 and L234 residues. The naphthyl ring formed a $\pi-\pi$ stacking interaction with Y188 and W229 residues. The central catechol ring is responsible for the interaction with Y181 via $\pi-\pi$ interaction.

\subsection{Anti-HCV Agents}

DE showed itself to be a favourable group in the development of inhibitors targeting RNA-dependent RNA polymerase (RdRp, NS5B). This enzyme plays a crucial role in $\mathrm{HCV}$ replication and is an important molecular target used for anti-HCV drugs design. Talele et al. showed that the incorporation of DE moiety into the thioxothiazolidin-type inhibitor (13) improved its activity (7-fold more potent inhibitor-compound 14). It is probably because of the strong $\pi$-cation and hydrophobic interactions between $\mathrm{DE}$ and NS5B protein [30]. Inhibitor $\mathbf{1 4}$ possesses another privileged structure, rhodanine, which is described later.

In 2013, Stammers et al. discovered potent anthranilic acid-based NS5B polymerase inhibitors. Compound $\mathbf{1 5}$ with 3-trifluoromethylpyridin-2-yl group introduced into the DE moiety showed low $\mathrm{IC}_{50}$ and $\mathrm{EC}_{50}$ values [31]. Later, the same group applying the SAR approach discovered compound $\mathbf{1 6}$ as a highly potent inhibitor HCV NS5B polymerase with antiviral activity against HCV genotypes $1 \mathrm{a}$ and $1 \mathrm{~b}$ [32]. Compounds 15 and 16 bind into the allosteric site of HCV NS5B polymerase (thumb pocket 2 ) and the modified DE group is essential for this interaction. 


\subsection{Anti-Flaviviruses Agents}

One of the promising anti-FLV agents are inhibitors of NS2B-NS3 protease, which is a key enzyme in the virus replication cycle, responsible for viral polyprotein processing. Benz[d]isothiazol-3(2H)-one-triazoles are a class of inhibitors reported in 2012 by Groutas's research group. They synthesised para- and meta-substituted aminobenzamide derivatives. Planar aminobenzamide allows fitting the inhibitor into the shallow active site of DENV and WNV proteses; additionally, aminobenzamide structure orienting substituents to interact with multiple active site residues. The studies led to the discovery of inhibitor $\mathbf{1 7}$ containing DE moiety in its structure, which was found to be active against both DENV $\left(\mathrm{K}_{\mathrm{i}}=8.77 \mu \mathrm{M}\right)$ and WNV NS2B-NS3 $\left(K_{i}=5.55 \mu \mathrm{M}\right)$ proteases [33]. Molecular docking studies revealed hydrophobic interactions between the DE group and Val72. Grouta's group also discovered a potent inhibitor of noroviruses-compound 18. This heterocyclic compound with DE part showed $\mathrm{EC}_{50}=4 \mu \mathrm{M}$ and is a good starting point for the development of new antinorovirus agents [34].

\subsection{Anti-Polyomaviruses Agents}

Polyomaviruses compose a family of small double-stranded DNA viruses. Although an infection with these viruses does not cause serious diseases, nevertheless, in immunocompromised patients (e.g., patients after kidney transplantation), it can trigger a progressive multifocal leukoencephalopathy or polyomavirus-associated nephropathy. The DE scaffold was found to be beneficial for the development of John Cunningham virus (JCV) and $B K$ virus (BKV) helicase inhibitors. SAR studies led to the discovery of the potent inhibitor 19 of helicase from JCV and BKV. Crystallographic data indicates that the phenoxy group of DE is responsible for the cation $-\pi$ interaction with Arg555 and Lys419 of helicase. An incorporation of a nitrogen atom into the aromatic ring ensures H-bonds interaction with helicase Lys419. This inhibitor showed antiviral activity in vero cells with an $\mathrm{EC}_{50}$ value of $40 \mu \mathrm{M}$ against JCV with no significant cytotoxicity [35].

\subsection{Anti-Rhinoviruses Agents}

Compound 20 was found to be a potent inhibitor of rhinovirus replication. This small molecule is responsible for the interaction with viral coat protein 1 (VP1) and impedes viral infection at an early stage. Compound 20 inhibited the replication of hRV-B14, A21 and A71 strains with $\mathrm{EC}_{50}$ values of $0.083 \mu \mathrm{M}, 0.078 \mu \mathrm{M}$ and $0.015 \mu \mathrm{M}$, respectively. These values are in a range of Pleconaril activity - the antiviral drug used in the common cold symptoms [36]. DE moiety is part of the N-methyl-picolinamide-based inhibitors in which it is crucial for the antiviral effect. As molecular docking studies have shown, N-methylpicolinamide moiety creates hydrophobic interactions with L106, Y197 and M221 in VP1. Compound 20 exhibit strong inhibition toward poliovirus 3 replication with the $\mathrm{EC}_{50}$ of $0.063 \mu \mathrm{M}[37]$.

\subsection{Host-Targeting Antivirals}

In order to enter the host cell and efficiently replicate inside, viruses use a wide range of host factors that are crucial for virus spread. Thus, more and more attention is directed to the development of inhibitors targeting host enzymes participating in the replication. One of the promising host factors for antiviral intervention is dihydroorotate dehydrogenase (DHODH), an enzyme essential for the synthesis of pyrimidine, crucial for the biosynthesis of DNA, RNA and phospholipids building blocks [38]. Compound 21 is a potent DHODH inhibitor with a low nanomolar $\mathrm{IC}_{50}$ value $\left(\mathrm{IC}_{50}=1 \mathrm{nM}\right)$. This compound showed a broadspectrum antiviral activity. The cell-based assays showed the $\mathrm{IC}_{50}$ value of $2 \mathrm{nM}$ against vesicular stomatitis virus (VSV) and the $\mathrm{IC}_{50}$ of $41 \mathrm{nM}$ against influenza $\mathrm{A} / \mathrm{WSN} / 33$ virus. This inhibitor was developed during the SAR study. The DE group present in the structure of 21 is important for its activity since it creates $\pi-\pi$ stacking with the phenylalanine side chain (Phe62) of DHODH. Analogues without the DE group displayed a significant loss of activity against DHODH (260-fold increase of the $\mathrm{IC}_{50}$ value) [39]. 
Another interesting SAR study undertaken by Yang et al. led to 22 as a potent broad spectrum antiviral agent. This quinolone-based DE scaffold-containing compound was found to be a potent DHODH inhibitor with $\mathrm{EC}_{50}=0.015 \mu \mathrm{M}$. As a strong DHODH inhibitor, the compound 22 showed low $\mathrm{IC}_{50}$ values against a wide range of viruses: $4 \mathrm{nM}$ against EV71, $5 \mathrm{nM}$ against $\mathrm{HCV}, 7 \mathrm{nM}$ against DENV $\mathrm{IC}_{50}=13 \mathrm{nM}$ against HIV. The binding mode of 22 to the DHODH is similar to the inhibitor 21, where the DE group interacts with the aromatic ring of phenylalanine via $\pi-\pi$ stacking interaction [40].

\section{Indole}

The indole ring is one of the most important privileged scaffolds employed in drug discovery. A tremendous number of compounds containing this heterocyclic aromatic ring structure are already approved drugs or are currently under clinical trials. In 2015, Zhang et al. published a comprehensive review describing antivirals with indole core [41] while in 2019 and 2020, Kumari et al. and Durababu presented reviews about medicinal chemistry of indole derivatives describing indole containing antivirals [42,43]. Considering the above, we refer to studies published after 2019 in regard to the application of indole ring in antiviral drug discovery. We also briefly present the already approved antiviral drugs containing indole moiety.

Indole ring is a pervasive/ubiquitous motif present in many natural products like the side chain of tryptophan (23), one of the naturally occurring proteinogenic amino acids, or neurotransmitters including serotonin (24), as well as in hormones such melatonin (25) (Figure 3). The structure of indole is present in many drugs, including antiviral (Table 1), antibacterial, antimalarial or anti-tumor agents. Such a diversity may by partially explained by relatively easy modification of the indole ring.

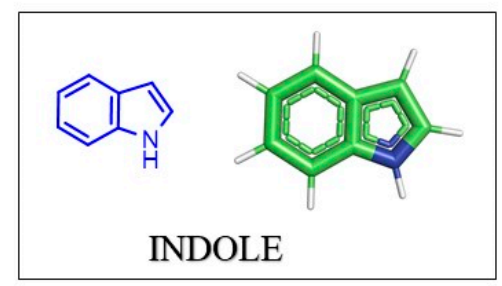

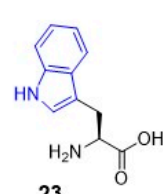

23

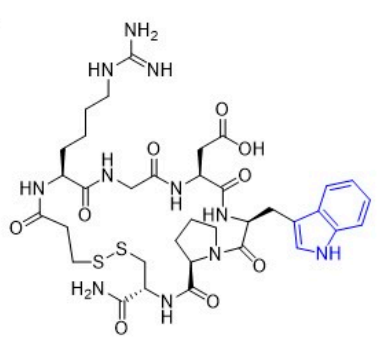

36

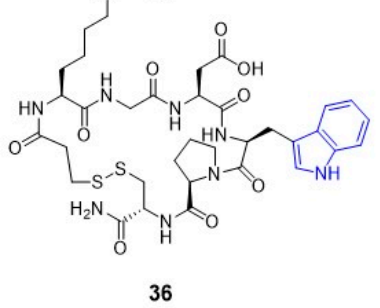

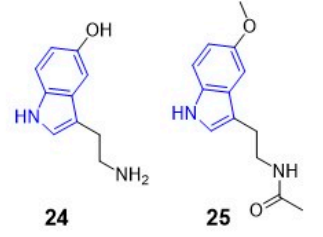
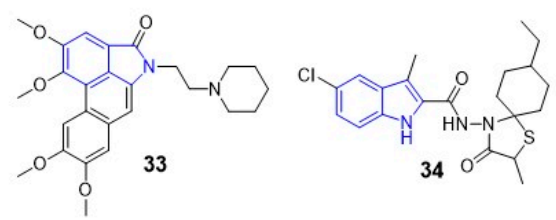

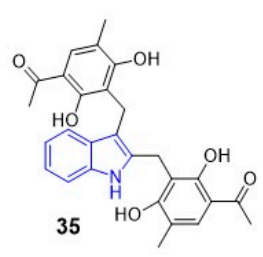

Figure 3. Important compounds (23-25) and antivirals (33-35) with indole ring. 
Table 1. Accepted antivirals with indole ring.

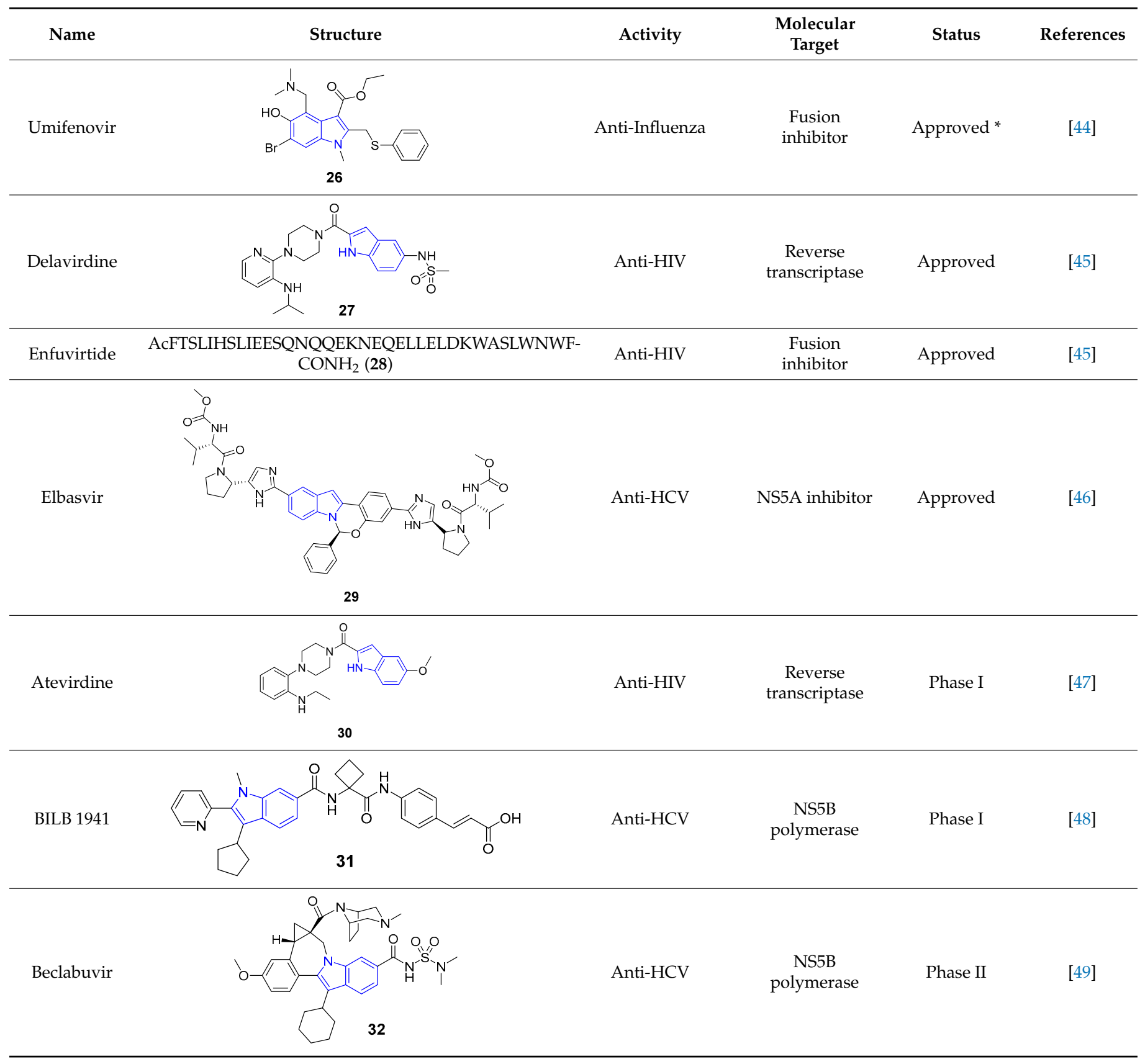

* Drug approved only in the Russia and China.

\subsection{Anti-HIV Agents}

In 2020, Young Hyun Shin et al. presented the anti-HIV activity of aristolactam derivatives based on the dibenzo[cd,f]indol-4(5H)-one structure [50]. The most active compound from the studies (33) showed the $\mathrm{IC}_{50}$ value of $1.03 \mu \mathrm{M}\left(\mathrm{CC}_{50}=16.91 \mu \mathrm{M}\right)$. Interestingly, compound 33 is not an HIV-1 reverse transcriptase inhibitor but impedes Tatmediated viral transcription. This pathway have been already targeted by different class of inhibitors [51-53]. The findings of Young Hyun Shin et al. suggest that aristolactams derivatives can be considered as an interesting starting point for the development of a novel class of anti-HIV-1 agents which inhibit the HIV-1 Tat-mediated transcription. 


\subsection{Anti-Influenza Agents}

Recently, the Naesens group developed inhibitors of the membrane fusion of the influenza virus [54]. The inhibitor with this mode of action-umifenovir (26)-is currently used in influenza treatment. Presented compounds contain an indole ring within the spirothiazolidinone structure. The most potent inhibitor from these studies (34) showed an $\mathrm{EC}_{50}$ value of $1 \mathrm{nM}$ against influenza $\mathrm{A} / \mathrm{H} 3 \mathrm{~N} 2$ virus with a cytotoxicity $\mathrm{CC}_{50}=1.5 \mu \mathrm{M}$. Molecular docking studies revealed the possible conformations of the inhibitor. The positively charged indole nitrogen of $\mathbf{3 4}$ interacts with solvent via electrostatic interactions and the charged residues present in the enzyme binding pocket, such as E572 of monomer 1.

Recently, the concept of dual inhibitors, also known as designed multiple ligands (DMLs), is attracting great attention in the scientific community. The DMLs concept was introduced by Richard Morphy and Zoran Rancovic [55,56]. Among other things, such an unconventional approach was used during anti-HIV agent development [57,58]. As representative examples could serve dual inhibitors of Tat-mediated transcription and reverse transcriptase [59]. Bifunctional inhibitors of reverse transcriptase and integrase inhibitors are also known [60]. In 2020, Guangwei Wu et al. proposed anti-influenza A virus (IAV) agents displaying a dual inhibitory activity: blocking hemagglutinin-mediated adsorption of the virus particle from one side, and blocking the process of membrane fusion from the other side [61]. From a series of fifteen compounds, inhibitor $\mathbf{3 5}$ was found as a potent and broad-spectrum anti-IAV agent. In a single-cycle, replication assay, 35 showed the $\mathrm{IC}_{50}$ values of $6.3 \mu \mathrm{M}, 5.5 \mu \mathrm{M}$ and $9.5 \mu \mathrm{M}$ against H1N1, H3N2, H1N1 virus subtypes, respectively. In the same assay, umifenovir (26), known as the influenza virus fusion inhibitor, displayed the $\mathrm{IC}_{50}$ value of $13.3 \mu \mathrm{M}$. The structure of 35 is built on the central indole ring scaffold substituted at C-2 and C-3 positions. This is the first IAV inhibitor targeting both HA1 and HA2 subunits of virus hemagglutinin; thus, it is able to block both the IAV adsorption and membrane fusion. Molecular dynamic simulations showed that the indole ring is oriented to the center of the binding site forming $\mathrm{T}-\pi$ interactions with tryptophan side chain (W14) of monomer 1 . This compound could be considered as the proof of the concept that drugs which inhibit multiple hemagglutinin functions are effective for therapy of influenza infections.

\subsection{Anti-Alphavirus Agents}

In 2020, Fatma et al. reported Eptifibatide Acetate (36) as a potent chikungunya virus capsid protease $(\mathrm{CP})$ inhibitor [62]. This compound also suppressed the viral replication in a cell-based assay showing an $\mathrm{EC}_{50}$ value of $4.01 \mu \mathrm{M}$. Considering the $\mathrm{CP}$ substrate specificity at $\mathrm{P} 1$ position toward tryptophan residue, the indole ring present in the eptifibatide structure most likely fits the S1 pocket of the protease.

\section{2-(1,3-Oxazinan-3-yl)ethan-1-amine and 2-(Piperidin-1-yl)ethan-1-amine \\ 4.1. Anti-HIV Agents}

A representative example of an antiviral agent containing the 2-(1,3-oxazinan-3yl)ethane structural motif is Cobicistat (GS-9350; 37, Figure 4) developed by Gilead Sciences. GS-9350 is the inhibitor of human cytochrome P450 3A (CYP3A) used in HIV-1 infection treatment [63].

Compounds with 2-(1,3-oxazinan-3-yl)ethan-1-amine moiety were found to be useful NNRTIs against mutant variants of HIV-1 reverse transcriptase [64], in particular, against $\mathrm{K} 103 \mathrm{~N}$ mutation. Compound 38 showed $\mathrm{EC}_{50}=49 \mathrm{nM}$, which is a significantly higher activity when compared with other known NNRTIs $\left(\mathrm{EC}_{50}=6.78 \mu \mathrm{M}\right.$ for NVP; $\mathrm{EC}_{50}=2.48 \mu \mathrm{M}$ for DLV and $\mathrm{EC}_{50}=0.12 \mu \mathrm{M}$ for $\mathrm{EFV}$ ). 2-(morpholinoethyl)amino group forms a hydrogen bond with Lys101, which probably plays an essential role in improving activity against the K103N mutant strain. These results highlight great potential of this lead compound for further optimization of new anti-HIV-1 agents. 


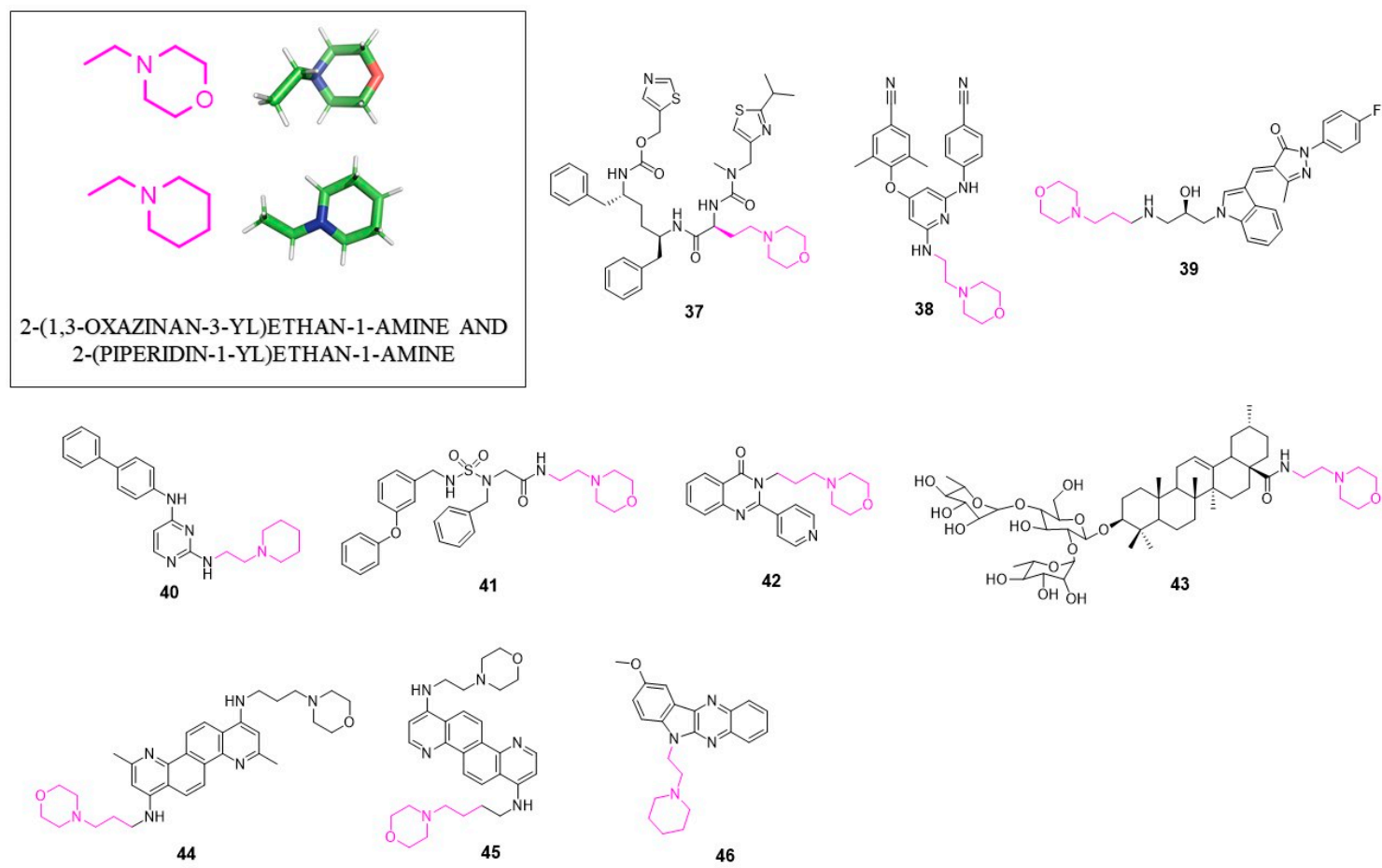

Figure 4. Antivirals with 2-(1,3-oxazinan-3-yl)ethan-1-amine and 2-(piperidin-1-yl)ethan-1-amine.

\subsection{Anti-HCV Agents}

In 2016, Han et al. developed several novel HCV inhibitors which block the step of virus entry [65]. The SAR studies identified compound 39 which displayed good anti$\mathrm{HCV}$ activity $\left(\mathrm{EC}_{50}=0.72 \mu \mathrm{M}\right)$ and high selectivity $(\mathrm{SI}>69.44)$ towards the cytotoxicity effect. Interestingly, in addition to 2-(1,3-oxazinan-3-yl)ethane, unit inhibitor 39 contains an indole ring, previously described as a privileged structure. The potency of compound 39 encourages the development of new anti-HCV agents based on its structure.

\subsection{Anti-Flavivirus Agents}

In 2019, a set of novel compounds targeting DENV E protein was presented [66]. The de novo design followed by molecular dynamics optimization led to 40 , which was the most potent compound of the series active against all four serotypes of DENV (DENV1-DENV4) with the $\mathrm{EC}_{50}$ value of $0.87 \mu \mathrm{M} ; 0.85 \mu \mathrm{M} ; 0.56 \mu \mathrm{M} ; 2.5 \mu \mathrm{M}$ against DENV1, DENV2, DENV3, DENV4, respectively, and $\mathrm{CC}_{50}=18.1 \mu \mathrm{M}$ and a satisfactory in vitro pharmacokinetics profile with solubility in simulated gastric fluid $506 \mu \mathrm{g} / \mathrm{mL}$ and $\mathrm{t}_{1 / 2}>120 \mathrm{~min}$.

\subsection{Anti-Norovirus Agents}

In 2012, the synthesis of acid-derived acyclic sulfamide-based inhibitors of norovirus was reported [67]. From a diversified library of compounds, $\mathbf{4 1}$ was the most potent with the $\mathrm{EC}_{50}$ value of $3.8 \mu \mathrm{M}$ and the $\mathrm{TD}_{50}$ value of $45 \mu \mathrm{M}$ in a cell-based replicon assay. Interestingly, the mechanism of action of this type of inhibitors remains unknown.

\subsection{Anti-Influenza Agents}

Liu et al. developed new 2-pyridinyl-3-substituted-4(3H)-quinazolinones as antiinfluenza A virus agents [68]. Compound $\mathbf{4 2}$ was one of the most potent with the $\mathrm{IC}_{50}$ value of $54 \mu \mathrm{M}$ against H1N1. Further studies of its mechanism of action revealed that this class of inhibitors impedes virus neuraminidase activity as well as the cellular NF- $\kappa \mathrm{B}$ signaling pathway.

In 2019, Hui Li et al. described new entry inhibitors of influenza virus [69]. An incorporation of 2-(piperidin-1-yl)ethan-1-amine and 2-(1,3-oxazinan-3-yl)ethan-1-amine structures into $3-\mathrm{O}-\beta$-chacotriosyl ursolic acid via an amide bond resulted in the generation 
of novel IAV inhibitors. Compound 43 showed the $\mathrm{IC}_{50}$ values of $4.13 \mu \mathrm{M}, 18.18 \mu \mathrm{M}$ and $20.12 \mu \mathrm{M}$ against H5N1, H1N1 and H3N2, respectively. Most probably, 43 is able to bind to the viral hemagglutinin (HA). The molecular docking studies showed that $\mathbf{4 3}$ fits into the conserved pocket in the trimeric form of HA. Considering its activity, compound $\mathbf{4 3}$ is an excellent lead structure for further development of more potent anti-IAV agents.

\subsection{Anti-Ebola Agents}

Compound 44 is a symmetrical molecule containing two 2-(1,3-oxazinan-3-yl)ethan1 -amine groups in its structure [70]. It was discovered during the work focused on new Plasmodium falciparum inhibitors. It showed in vitro the $\mathrm{IC}_{50}$ value of $2.5-5 \mu \mathrm{M}$ in a EBOV assay. Possibly this compound targets some host cellular pathways important for virus replication. Furthers studies are needed to confirm this hypothesis. Further studies revealed that analogous compound to 44 inhibitor 45 administered at a low dose $(10 \mathrm{mg} / \mathrm{kg} /$ day $)$ showed in mouse models $100 \%$ protection against Ebola virus [71]. In the HeLa cells, assay 45 displayed the $\mathrm{EC}_{50}$ value of $0.26 \mu \mathrm{M}$.

\subsection{Anti-Vaccinia Virus Agents}

Vaccinia virus (VACV) is a double-stranded DNA virus of the Poxviridae family. Its similarity to the variola virus (smallpox) makes it a good model to use for evaluation of novel agents targeting serious potential biothreat. The virtual screening of diversified combinatorial library led to the identification of potential nucleic acid intercalators with anti-vaccinia activity [72]. The most promising compound (46) inhibits virus reproduction with the $\mathrm{IC}_{50}$ value of $5 \mu \mathrm{M}$ and $\mathrm{SI}=34\left(\mathrm{SI}=\mathrm{CC}_{50} / \mathrm{IC}_{50}\right)$. These findings could serve as a starting point for the development of broad-spectrum antivirals of mechanism based on nucleic acid intercalation.

\section{Artemisinin (ART)}

Artemisinin (ART; 47, Figure 5) is a natural product derived from the Chinese herb Artemisia annua. Originally, this compound was identified as a strong anti-malaria agent winning for Youyou Tu the 2015 Nobel Prize in Physiology or Medicine for key contributions to the discovery of artemisinin [73]. Apart from its anti-malaria activity, artemisinin shows anticancer activity. Interestingly, the bioactivity of artemisinin and its derivatives encompasses also inhibition of viruses including the Herpesviridae family (human cytomegalovirus, herpes simplex virus type 1 or Epstein-Barr virus), hepatitis B and hepatitis $C[74,75]$.

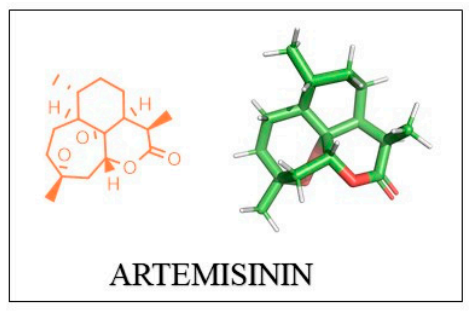

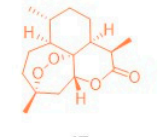

47

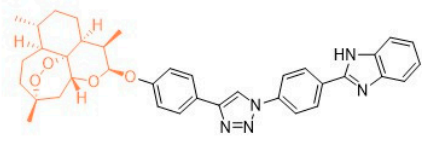

52

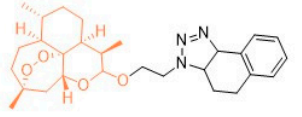

48

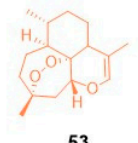

53

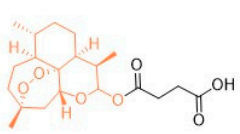

49

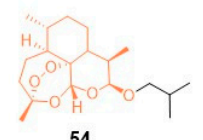

54
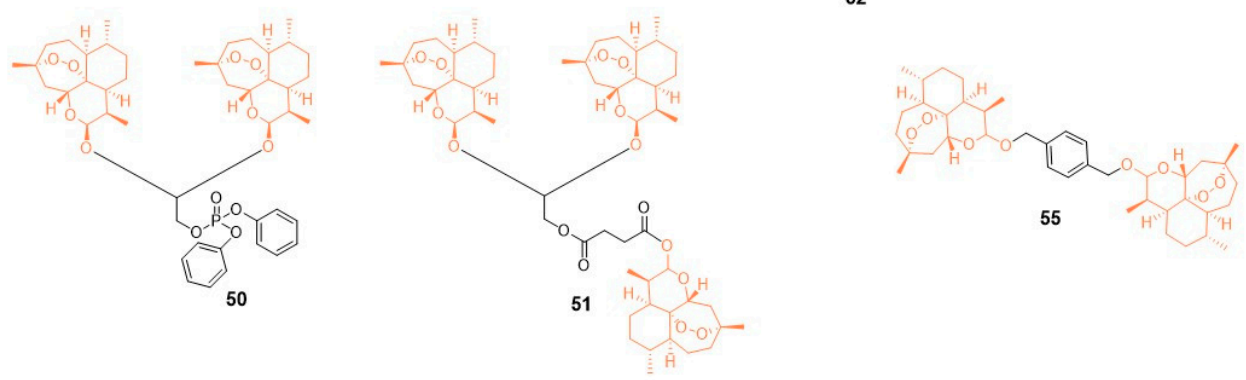

Figure 5. Artemisinin derivatives with antiviral activity. 


\subsection{Anti-HIV Agents}

In 2017, Jana et al. synthesized a library of fused 1,5-disubstituted 1,2,3-triazole artemisinin derivatives [76]. The most active inhibitor 48 showed an $\mathrm{IC}_{50}$ value of $2.78 \mu \mathrm{M}$ against HIV-1 $\mathrm{III}_{\mathrm{B}}$. Although this activity is significantly higher when compared to Etravirine, which showed the $\mathrm{IC}_{50}$ value of $3.4 \mathrm{nM}$ in the same assay, the authors postulated that the developed compound acts as a first generation NNRTI since it lacks the activity against the double reverse transcriptase mutant (K103N; Y181C) of HIV-1 (strain RES056) with $\mathrm{IC}_{50}>31.5 \mu \mathrm{M}$.

\subsection{Anti-Flavivirus Agents}

Recently, the Jing Ye research group discovered that artemisinin (47) could be useful as a therapeutic agent able to inhibit the replication of flaviviruses such as Japanese encephalitis (JEV), Dengue virus (DENV) and Zika virus (ZIKV) [77]. The authors also investigated the mode of artemisinin action showing that upon viral infection, ART enhances the host type I interferon production. Animal-based studies showed that JEV-infected mice treated with ART showed the reduction of viremia, neuroinflammation and mortality. Taken together, ART could be advantageous as a broad-spectrum inhibitor of flaviviruses.

\subsection{Anti-Herpesvirus Agents}

Artesunate (ARS; 49) is a synthetic derivative of the natural artemisinin used in malaria treatment, which displays activity against human cytomegaloviruses [78,79]. Sunwen Chou et al. described new discoveries in regard to anti-CMV activity of ART [80]. They showed that ART is able to block CMV standard therapy-resistant virus mutants with a 2-fold range compared to wild-type virus (e.g., $\mathrm{IC}_{50}=3.26 \mu \mathrm{M}$ for WT vs. $\mathrm{IC}_{50}=6.25 \mu \mathrm{M}$ for L595S mutant in HEL cells). They also found that ART treatment of HCMV-infected cells after virus adsorption enhance antiviral activity. ART showed a synergistic effect in combination with inhibitor of viral protein kinase maribavir (MBV).

In 2011, Ran He et al. found that artemisinin-derived dimers are more potent inhibitors of human cytomegalovirus (CMV) replication than artemisinin-derived monomers [81]. The most active compound from the studies $\mathbf{5 0}$ containing diphenyl phosphate (DPP) function showed $\mathrm{EC}_{50}=0.04 \mu \mathrm{M}$ with $\mathrm{CC}_{50}=55.8 \mu \mathrm{M}$, while in the same assay, the reference compound ganciclovir displayed $\mathrm{EC}_{50}=2.7 \mu \mathrm{M}$ with $\mathrm{CC}_{50}=247 \mu \mathrm{M}$. Compound 50 showed the strong inhibitory effect on the growth of cancer cell lines (HeLa, 1205Lu, HCT116, HFF). Later, the same research group tried to optimize the $\mathbf{5 0}$ structure. The replacement of phenyl rings in diphenyl phosphate moiety resulted in activity loss. Only the molecule with the dicyclohexylphosphate unit showed activity comparable to that of the lead compound $\left(\mathrm{EC}_{50}=0.044 \mu \mathrm{M}\right)$ [82]. Further studies on $\mathbf{5 0}$ showed that this dimer is an irreversible CMV inhibitor. Interestingly, the analog devoid of the peroxide unit within the artemisinins structure showed lowest anti-CMV activity [83].

In 2015, Reiter et al. developed the artemisinin-derived trimer (51) without DPP function which displayed a $\mathrm{IC}_{50}$ value of $0.04 \mu \mathrm{M}$, very similar to the DPP artemisinin dimer [84]. Compound 51 showed high potency against CCRF-CEM and CEM/ADR5000 leukemia cell lines with activity greater than the reference compound, i.e., doxorubicin.

Recently, the monomeric anti-CMV derivative of artemisinin containing a triazole unit in its structure was reported [85]. Compound 52 showed $\mathrm{EC}_{50}=0.26 \mu \mathrm{M}$ and low cytotoxicity $\left(\mathrm{CC}_{50}>60 \mu \mathrm{M}\right)$ while its autofluorescent properties helped to localize it inside the cell. BF95 accumulates in the mitochondria and reduces mitochondrial membrane potential. The analogue compound without the endoperoxide bridge did not show any antiviral activity and had no impact on mitochondrial membrane potential. This observation suggests the importance of mitochondria in the antiviral mechanism of artemisinin derivatives action. 


\subsection{Anti-HBV Agents}

In 2005, the anti-HBV properties of ART and ARS were demonstrated on the in vitro model of HepG2 2.2.15 [46], which led to the discovery of new artemisinin derivatives with potential antiviral properties [86]. From eight new compounds, inhibitors $\mathbf{5 3}$ and $\mathbf{5 4}$ were able to reduce the release of HBV-DNA to the medium at non-toxic concentrations in HepG2 cells permanently infected with hepatitis B virus.

\subsection{Anti-HCV Agents}

ART was found to inhibit the HCV replication in vitro at concentrations that have no effect on host cell growth [87]. Later, ART analogs with enhanced activity were developed. Studies presented by Obeid et al. showed that inhibitor $\mathbf{5 5}$ is a potent anti-HCV agent in $\mathrm{a} /$ the Huh 5-2 HCV replicon assay with $\mathrm{EC}_{50}=3.2 \mu \mathrm{M}$ and $\mathrm{CC}_{50}>133 \mu \mathrm{M}$ [88]. Studies with carbon-centered radicals-trapping compound revealed that radicals are not the main effectors of the anti-HCV activity of the artemisinin derivatives. A possible mechanism of action of this compound includes the induction of reactive oxygen species (ROS).

\section{1,3,4-Oxadizole}

1,3,4-oxadiazole is a heterocyclic five-membered ring which is an important feature in new compounds, with numerous biological activities, such as anti-cancer, antiinflammatory, anti-bacterial, anti-protozoal and anti-viral. Compounds containing the 1,3,4-oxadiazole scaffold are known anti-HIV, anti-HCV, anti-HBV, anti-HAV and anti-HSV1 agents. In 2011 and 2017, two excellent reviews about the chemistry and biology of 1,3,4-oxadiazoles were published $[89,90]$. Herein, we supplement the information present in the mentioned articles.

\subsection{Anti-HIV Agents}

In 2018, Shah et al. showed results about new quinolines as anti-HIV agents. As the part of the work, they synthesized the 1,3,4-oxadiazole-quinoline hybrid. One of the compounds (56, Figure 6) showed $\mathrm{IC}_{50}=45 \mu \mathrm{M}$ and $135 \mu \mathrm{M}$ against HIV-1 $1_{\mathrm{VB} 59}$ and HIV$1_{\mathrm{UG} 070}$, respectively, with low cytotoxicity $\left(\mathrm{CC}_{50}=413.38 \mu \mathrm{M}\right)$ [91]. Better activity was observed for derivatives with $\alpha, \beta$-unsaturated amide moiety instead of 1,3,4-oxadiazole. The most active compound containing this structure displayed $\mathrm{IC}_{50}=3.35 \mu \mathrm{M}$ (against HIV-1 ${ }_{\text {VB59) }}$ and $2.57 \mu \mathrm{M}$ (against HIV-1 ${ }_{\text {UG070 }}$ ).

\subsection{Anti-Flavivirus Agents}

1,3,4-oxadiazole derivatives were found to be potent anti-flavivirus agents. Highthroughput screening and further SAR studies helped to develop potent inhibitors of viral NS5 polymerase [92]. The most active inhibitor with 1,3,4-oxadiazole moiety (57) showed $\mathrm{IC}_{50}=4.0 \mu \mathrm{M}$ in in a DENV-2 RdRp assay and $\mathrm{EC}_{50}=4.9-9.1 \mu \mathrm{M}$ against four DENV serotypes (DENV1-DENV4) with not cytotoxic effect in a Vero E6 cells assay $\left(\mathrm{CC}_{50}>100 \mu \mathrm{M}\right)$.

\subsection{Anti-Herpesvirus Agents}

Recently, El Mansouri et al. designed and synthesized a series of 1,3,4-oxadiazolepyrimidines and purines hybrids [93]. One of the compounds (58) showed a great potency of action against thymidine kinase-negative strain (TK-VZV) with $\mathrm{EC}_{50}=50 \mu \mathrm{M}$, which is two times better than the activity of Acyclovir $\left(\mathrm{EC}_{50}=103 \mu \mathrm{M}\right)$ and comparable with Brivudine $(35 \mu \mathrm{M})$. 


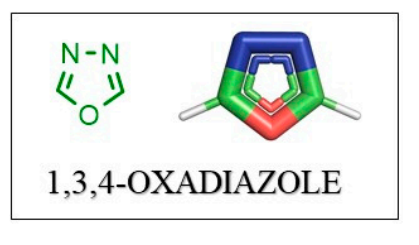

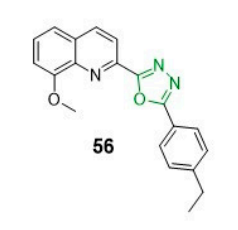

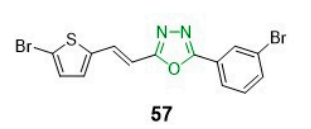

57
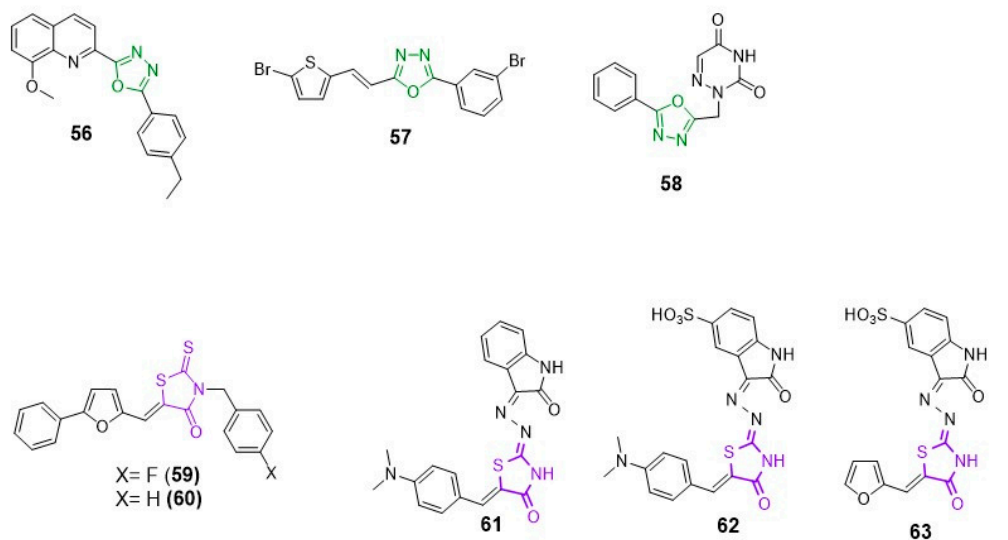

63

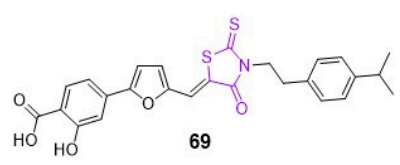

65
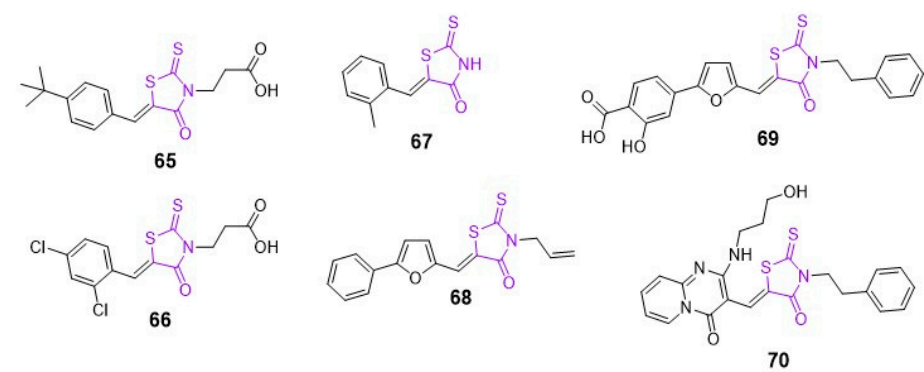

Figure 6. 1,3,4-Oxadiazole and rhodanine containing antivirals.

\section{Rhodanine (RHO)}

Rhodnanine (2-thioxothiazolidin-4-one) is a 5-membered heterocyclic structure present in several biologically active compounds including antibacterial, anticancer and antiviral agents [94]. Possible modifications of RHO structure are practically unlimited, which yields a great number of its derivatives. Rhodanine is most often substituent in 5 position; however, the introduction of a/the substituent in different positions is possible.

\subsection{Anti-HIV Agents}

In 2011, Botta's research group performed an optimization of the previously found inhibitor of HIV integrase $[95,96]$, which led to the discovery of a series of potent integrase inhibitors able to inhibit HIV-1 replication. Compounds 59 and $\mathbf{6 0}$ were the most potent derivatives displaying $\mathrm{IC}_{50}=6.9 \mu \mathrm{M} ; \mathrm{EC}_{50}=1.7 \mu \mathrm{M}$ for 59 and $\mathrm{IC}_{50}=3.7 \mu \mathrm{M}$ and $\mathrm{EC}_{50}=8.2 \mu \mathrm{M}$ for 60 . Molecular docking studies showed the existence of hydrophobic interactions between the rhodanine substituent of 59 and Y143 of HIV integrase.

The rhodanine scaffold is also found in nucleocapsid protein 7 (Ncp7) inhibitors. Ncp7 is a small nucleocapsid protein with the basic character. Since it is crucial for the viral replication at several stages and is found in all viral strains, Ncp7 is considered an attractive therapeutic target $[97,98]$. Researchers from Boehringer Ingelheim identified three potent rhodanine based Ncp7 inhibitors with IC50 values: $0.59 \mu \mathrm{M} ; 0.11 \mu \mathrm{M} ; 0.95 \mu \mathrm{M}$ for $\mathbf{6 1 ,} 62$ and 63, respectively [99]. The NMR based studies revealed the binding mode of inhibitor 3 . Ncp7 create two inhibitor binding sites (A and B). One molecule of the inhibitor binds to the A binding sites while the second inhibitor molecule interacts mainly with the $\mathrm{B}$ binding site and becomes a linker of these two binding sites. The rhodamine moiety of one inhibitor molecule interacts with the furan ring of the second inhibitor. 


\subsection{Anti-HCV Agents}

Rhodanine was found to be a favourable scaffold in the development of NS5B $\mathrm{HCV}$ polymerase inhibitors. In 2010, Talele et al. performed a virtual screening of 260,000 compounds and found the rhodanine scaffold-based molecule as good starting point for further SAR exploration and modification [30]. From all synthesized compounds, derivative 14 was the most potent inhibitor of NS5B with $\mathrm{IC}_{50}=4.26 \mu \mathrm{M}$. Molecular docking suggests the importance of the rhodamine scaffold in the interaction with viral enzyme; the $\mathrm{C}_{4}$ carbonyl oxygen atom of the rhodanine ring creates a hydrogen bond with the guanidine group of Arg503 of enzyme. The heterocyclic ring is stabilized by the side chains of Pro495 and W500. It is worth noting that compound $\mathbf{1 4}$ contains a DE unit which is another privileged scaffold discussed earlier.

\subsection{Anti-Flavivirus Agents}

As the continuation of the studies on the inhibitors of NS2B-NS3 protease, Klein's research group developed amide type thiazolidinedione-capped and rhodanine-capped inhibitors [100]. Generally, inhibitors with thiazolidinedione moiety showed better activity in an/the enzymatic assay; however, rhodanine-capped peptide hybrids had better antiviral activity in cell culture than the thiazolidinediones. The most potent rhodanine containing inhibitor (64) showed $\mathrm{IC}_{50}=6.1 \mu \mathrm{M}$ and $\mathrm{K}_{\mathrm{i}}=9.3 \mu \mathrm{M}$, while in antiviral assay, 64 had $\mathrm{EC}_{50}=16.7 \mu \mathrm{M}$.

In 2012, Stahla-Beek reported the first inhibitors that target the guanylyltransferase activity of the flavivirus NS5 RNA capping enzyme with antiviral properties [101]. HTS identified a series of rhodamine containing low molecular weight inhibitors of the dengue virus NS5 RNA capping enzyme. Further SAR analysis led to 65 (BG323), which was able to efficiently inhibit the West Nile virus and yellow fever virus in cell-based assays. 65 showed $\mathrm{Ki}=7.5 \mu \mathrm{M}$ and $9.5 \mu \mathrm{M}$ against dengue virus and yellow fever virus capping enzymes, respectively. $\mathrm{EC}_{50}$ for this compound in a dengue virus replicon antiviral activity assay reached $30.8 \mu \mathrm{M}$ with relative low cytotoxicity $\left(\mathrm{CC}_{50}=184 \mu \mathrm{M}\right)$. Interestingly, another inhibitor, 66 (BG330, $\mathrm{Ki}=9.8 \mu \mathrm{M}$ and $9 \mu \mathrm{M}$ against dengue virus and yellow fever virus, respectively), in a cell-based assay showed $\mathrm{EC}_{50}=2.6 \mu \mathrm{M}$, which is almost 12 times better than BG-323. Unfortunately, the cytotoxicity of BG330 was significantly higher than BG323 $\left(C_{50}=12 \mu \mathrm{M}\right)$. Molecular docking showed that central rhodamine adjusts substituents into enzyme binding pockets and possible hydrogen bond formation between Lys13 and oxygen atom of rhodanine.

Recently, Quek et al. used a fragment screening approach in order to search for novel anti-ZIKV protease agents [102]. This approach is one of the commonly used techniques in drug development. Screening of the compound library allowed the identification of low molecular ligands whose bonding modes are determined by X-ray crystallography or NMR spectroscopy. Further structures optimization allow highly active molecules $[103,104]$. Quek at al. found that the compound that was efficiently bound to the S1 pocket of the enzyme was rhodanine. Crystallographic data showed an interaction between rhodaniene and the enzyme. The hydrogen bond between oxygen of RHO and S135 as well as between the amide group and the hydroxyl group from Y130 were identified. These data suggest that the rhodanine scaffold can be used as a starting point for further development of more potent inhibitors of ZIKV protease. 


\subsection{Anti-Alphavirus Agents}

In 2015, Jadav et al. synthesized and studied the antiviral activity of new rhodanie derivatives [105]. Five compounds from the studies were identified as active inhibitors of chikungunya virus. The most potent derivative 67 showed $\mathrm{IC}_{50}=0.42 \mu \mathrm{M}$. Molecular docking suggests that compound 67 may act as an nsp2 CHIV protease inhibitor. Most probably, the rhodamine ring fits into the $\mathrm{S} 2$ pocket while aryldiene substituent occupies the S3 pocket. Further studies are necessary to verify this assumption.

\subsection{Broad Spectrum Antivirals}

Compound 68 is known as an antiviral molecule active against various enveloped viruses including influenza A, filoviruses, poxviruses, arenaviruses, bunyaviruses, paramyxoviruses, flaviviruses and HIV-1 [106]. Compound 68 contains an allyl moiety in 3 position and 2-phenylofuryl group substituted in 5 position of rhodamine moiety. SAR studies showed that both groups are essential for the compound's activity. It showed $\mathrm{IC}_{50}=1 \mu \mathrm{M}$ against nipah virus in a neutralization assay. The broad-spectrum activity is the result of its mechanism of action. It inhibits viral entry at a step after virus binding to the cell but before virus cell fusion via intercalation into the viral membrane. Further studies revealed the exact molecular mechanism of $68^{\prime} \mathrm{s}$ action. Compound 68 induces viral membrane lipid oxidation by singlet oxygen $\left({ }^{1} \mathrm{O}_{2}\right)$ generation. This event negatively impacts the viral membrane and impedes virus-cell fusion. Since the mechanism of action of $\mathbf{6 8}$ is strongly dependent on light, its use in antiviral therapy is of limited application $[107,108]$.

In 2018, Cagno et al. presented studies on the development of compounds similar to LJ001 $[109,110]$. The most potent compound was derivative 69 with $\mathrm{EC}_{50}=6.55 \mu \mathrm{M}$ against HSV-2 and $\mathrm{EC}_{50}=1.6 \mu \mathrm{M}$ against HSV-2 acyclovir-resistant strain. Derivative 69 was also active against other enveloped viruses such as HSV-1, HCMV, RSV, ZIKV, IAV and VSV remaining inactive against non-enveloped viruses. These data suggest a mechanism of action similar to that of LJ001 and cast considerable doubt on its application of 69 in antiviral therapy.

\subsection{Host Factors-Targeting Antivirals}

One of the most essential host factors required for viral replication is the DEAD-box RNA helicase/ATPase DDX3. Maga et al. developed new DDX3 inhibitors with active in enzyme assay and in infected cells [111]. Compound $\mathbf{7 0}$ was the most active against target DDX3 enzyme showing $\mathrm{K}_{\mathrm{i}}=0.2 \mu \mathrm{M}$ able to suppress HIV-1 replication $\left(\mathrm{EC}_{50}=6.5 \mu \mathrm{M}\right)$. Although the cytotoxicity of 70 is significant $\left(\mathrm{CC}_{50}=65 \mu \mathrm{M}\right)$, this compound might be a useful template to design more specific DDX3 inhibitors.

\section{Pyrrolo[2,3-d]pyrimidine (7-deazopurine) Nucleoside}

This group of compounds mimics purines (occurring in DNA and RNA). As such, it could replace purine nucleosides in DNA and RNA. 7-deazapurine structure could be modified in a variety of ways including C6, C7, C8 substitution as well as the generation of fused heterocyclic rings. Such heterocyclic unit can provide efficient $\pi-\pi$ or cation$\pi$ stacking interactions between active molecule and target protein. In 2017, Perlikova and Hocek published a review article describing antitumor and antiviral properties of 7-deazapurines [112]. Compounds with the 7-deazapurine scaffold are potent inhibitors of RNA-dependent RNA polymerase (NS5B) with anti-HCV activity. 7-deazapurine nucleosides effectively inhibit viruses of the Flaviviridae family (DENV, ZIKV, WNV, YFV), herpesviruses, HBV, HRV-C or EV71. 
Recently, Lin et al. designed and synthesized a series of novel 7-deazapurines displaying anti-DENV properties. Inhibitor 71 showed $\mathrm{EC}_{50}=2.08 \mu \mathrm{M}$ and $\mathrm{CC}_{50}=150.06 \mu \mathrm{M}$ [113] (Figure 7). Inhibitor $\mathbf{7 1}$ was active against four serotypes of DENV (DENV1-DENV4), which suggests that the target of these compounds is highly conserved among different DENV types. Most likely, compound $\mathbf{7 1}$ inhibits RNA polymerase, though further studies are needed to confirm this hypothesis.
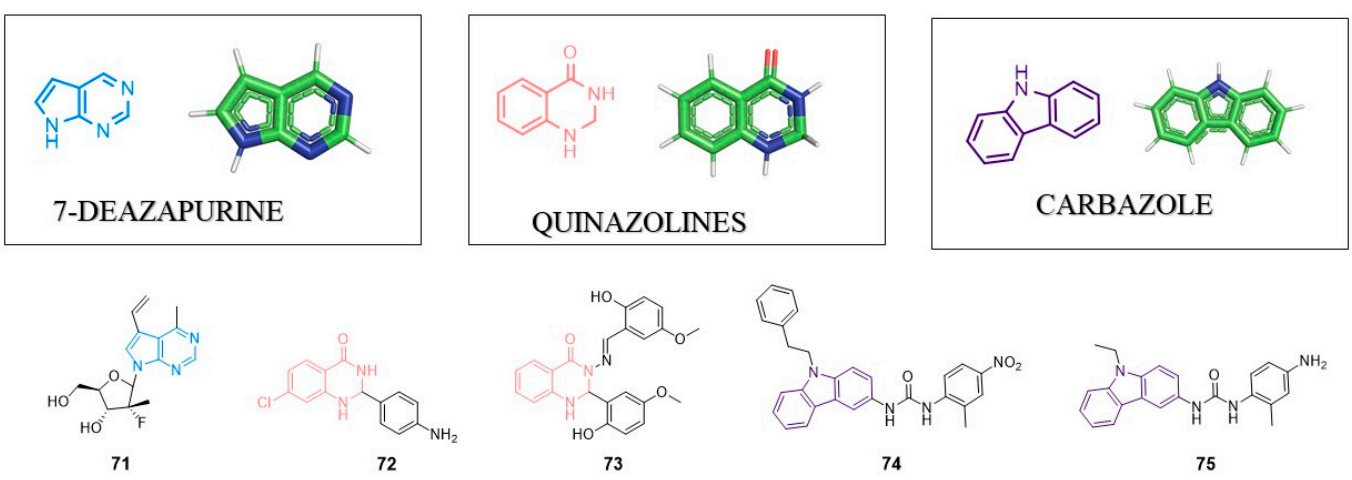

Figure 7. Examples of antivirals wit 7-deazapurine, quinazoline and carbazole moiety.

\section{Quinazolines}

Derivatives of these heterocyclic scaffolds/this heterocyclic scaffold are known due to a wide range of biological activity including anti-viral properties. Quinazolines could be divided into two groups: quinazolin-2(1H)-one and quinazolin-4(3H)-one. In 2018, Alagarsamy et al. provided a comprehensive review about quinazolines and their pharmaceutical activity [114]. The quinazoline scaffold is present in inhibitors of HIV-1, HIV-2, HSV-1, CMV, JEV, influenza virus and vaccinia virus.

\subsection{Anti-HIV Agents}

In 2014, Modh et al. presented synthesis and biological activity of quinazoline-triazine derivatives [115]. However, these compounds showed high cytotoxicity in MT-4 cells and no specific anti-HIV activity was found for quinazoline-triazine derivatives.

Sancineto et al. performed virtual screening and identify quinazoline as ligand of cyclin-dependent kinase 9 (CDK9), which is critical for HIV-1 Tat-mediated transcription [116]. The most potent inhibitor (72) showed $\mathrm{IC}_{50}$ value $26.2 \mu \mathrm{M}$ against $\mathrm{CDK} 9$ and inhibits HIV reactivation from latently infected cells with $\mathrm{IC}_{50}=4.0 \mu \mathrm{M}$. Compound 72 showed no significant cytotoxicity in MT4 and OM-10.1 cells. These data suggest that compound 72 with quinazoline scaffold can serve as the template for further optimization.

\subsection{Anti-HCV Agents}

In 2019, Rothan et al. developed new quinazoline based inhibitors of HCV NS3-4A protease showing antiviral activity in a Huh-7 cells-based assay [117]. NS3-4A serine protease is known as a molecular target in anti-HCV therapy and inhibitors of this enzyme are already approved drugs. Inhibitor 73 was the most potent inhibitor of NS3-4A with $\mathrm{IC}_{50}=42 \mu \mathrm{M}$. In HCV replicon assay, 73 showed the reduction of Rluc activity at $40 \mu \mathrm{M}$ (over two times activity loose in Rluc activity). A molecular docking study revealed a possible bonding mode of 73 . Heterocyclic quinazoline moiety crates $\pi-\pi$ stacking interaction with enzyme. Although the activity of compound $\mathbf{7 3}$ is much weaker than that of the already known inhibitors, it could be considered as a good starting point for further optimization and the development of new class of anti-HCV agents. 


\section{Carbazole}

Heterocyclic carbazole with two benzene rings fused with a five-membered nitrogencontaining ring scaffold is present in the structure of several antiviral agents active against HIV, HCV, HCMV, HSV or human papilloma viruses (HPVs). In 2019, Caruso et al. published a review article about carbazole derivatives with antiviral activity [118]. Just to supplement this excellent review, at the end of 2019, Spizzichino et al. presented a series of novel molecules based on a carbazoyl-aryl-urea structure which were potent Zika virus NS5 methyltransferase able to suppress virus replication [119]. SAR studies led to the creation of compound 74 as the most active inhibitor of ZIKV-NS5MTase with $\mathrm{IC}_{50}=23 \mu \mathrm{M}$ in an enzyme-based assay. This compound did not show antiviral activity in cell-based assay. Moreover, the most active compound against ZIKV with $\mathrm{EC}_{50}$ of $1.67 \mu \mathrm{M}$ in cell-based assay (75) displayed poor inhibitory activity toward the NS5-MTase in vitro. Further studies are required to unravel these unclear results. A possible explanation is that compound 75 targets another viral enzyme different from NS5 methyltransferase.

\section{Conclusions}

In this review, we presented privileged structures in known anti-viral agents (Table 2). It is absolutely clear that particular motifs of organic compounds are particularly beneficial to the development of antivirals. Privileged structures displayed versatile binding properties and are able to provide potent and selective interaction with a range of different biological targets. Privileged structures provide good drug-like properties. The result of incorporation of the privileged structure into the molecule is the production of high quality leads ready for further drugs development. Since privileged structures provide active and selective ligands for multiple biological targets, their application helps to simultaneously search for clinical candidates in multiple therapeutic fields. It accelerates the research and development of novel candidate drugs. A possible approach with privileged structure application is the modification of exciting bioactive compounds or compound libraries with certain PS. This could lead to the structures with new biological activity. Although a lot of data are available, already more information about the mode of action of a particular compound is necessary to verify its usefulness. For instance, artemisinin derivatives could be active against a wide range of viruses because of their ability to induce the antiviral host factor production instead of interaction with different viral enzymes.

Another problematic issue is the existence of PAINS. One of the discussed privileged structures, rhodamine, is also a known PAINS. Despite the fact that rhodanine containing compounds is the subject of numerous studies, no rhodamine derivative has entered clinical trials [120]. Misidentification of the true hit leads to the waste of time and money to optimize the activity of wrong compounds.

Taken together, we predict that studies on exciting privileged structures as well as the identification of new advantageous scaffolds are only a matter of time. However, researchers should carefully check the real activity of the possible hits to avoid confusion with PAINS. 
Table 2. Privileged structures present in antiviral compounds.

\begin{tabular}{|c|c|c|c|c|c|c|c|c|c|c|c|}
\hline & & & Diaryl Ether & Indole & $\begin{array}{l}\text { 2-(1,3-Oxazinan-3- } \\
\text { yl)ethan-1-amine }\end{array}$ & Artemisinin & $\begin{array}{c}1,3,4- \\
\text { Oxadiazole }\end{array}$ & Rhodanine & 7-Deazapurine & Quinazolin & Carbazole \\
\hline \multirow{18}{*}{ 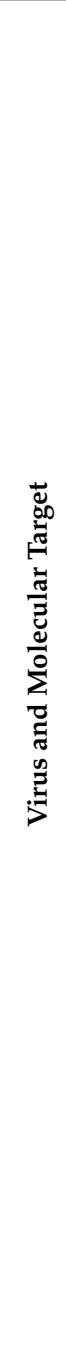 } & \multirow{4}{*}{ HIV } & $\begin{array}{c}\text { Reverse } \\
\text { transcriptase }\end{array}$ & [17-29] & {$[42,43]$} & [64] & [76] & {$[89,90]$} & & & [114] & [118] \\
\hline & & Fusion & & {$[42,43]$} & & & & & & & \\
\hline & & Ncp7 & & & & & & [99] & & & \\
\hline & & Tat & & [50] & & & & & & [116] & \\
\hline & \multirow{5}{*}{$\mathrm{HCV}$} & $\begin{array}{l}\text { NS3-4A } \\
\text { protease }\end{array}$ & & & & & & & & [117] & \\
\hline & & $\begin{array}{c}\text { NS5B } \\
\text { polymerase }\end{array}$ & [30-32] & {$[42,43]$} & & & [87] & [30] & [112] & & [118] \\
\hline & & NS5A protein & & [41] & & & & & & & \\
\hline & & Virus entry & & & [65] & & & & & & \\
\hline & & Unknown & & & & {$[70,71]$} & & & & & [118] \\
\hline & \multirow{7}{*}{ FLV } & $\begin{array}{l}\text { NS2B-NS3 } \\
\text { protease }\end{array}$ & [33] & & & & & {$[100,102]$} & & & \\
\hline & & $\begin{array}{c}\text { RNA } \\
\text { polymerase }\end{array}$ & & & & & [92] & & [112] & & \\
\hline & & E protein & & & [66] & & & & & & \\
\hline & & $\begin{array}{l}\text { NS5 RNA } \\
\text { capping } \\
\text { enzyme }\end{array}$ & & & & & & [101] & & & \\
\hline & & $\begin{array}{l}\text { NS5 methyl- } \\
\text { transferase }\end{array}$ & & & & & & & & & [119] \\
\hline & & $\begin{array}{l}\text { Interferon } \\
\text { production } \\
\text { enhancement }\end{array}$ & & & & [77] & & & & & \\
\hline & & Unknown & & & & & & & [113] & [114] & \\
\hline & \multirow{2}{*}{ IAV /IBV } & Fusion & & {$[54,61]$} & [68] & & & & & & \\
\hline & & Neuraminidase & & [61] & [69] & & & & & & \\
\hline
\end{tabular}


Table 2. Cont.

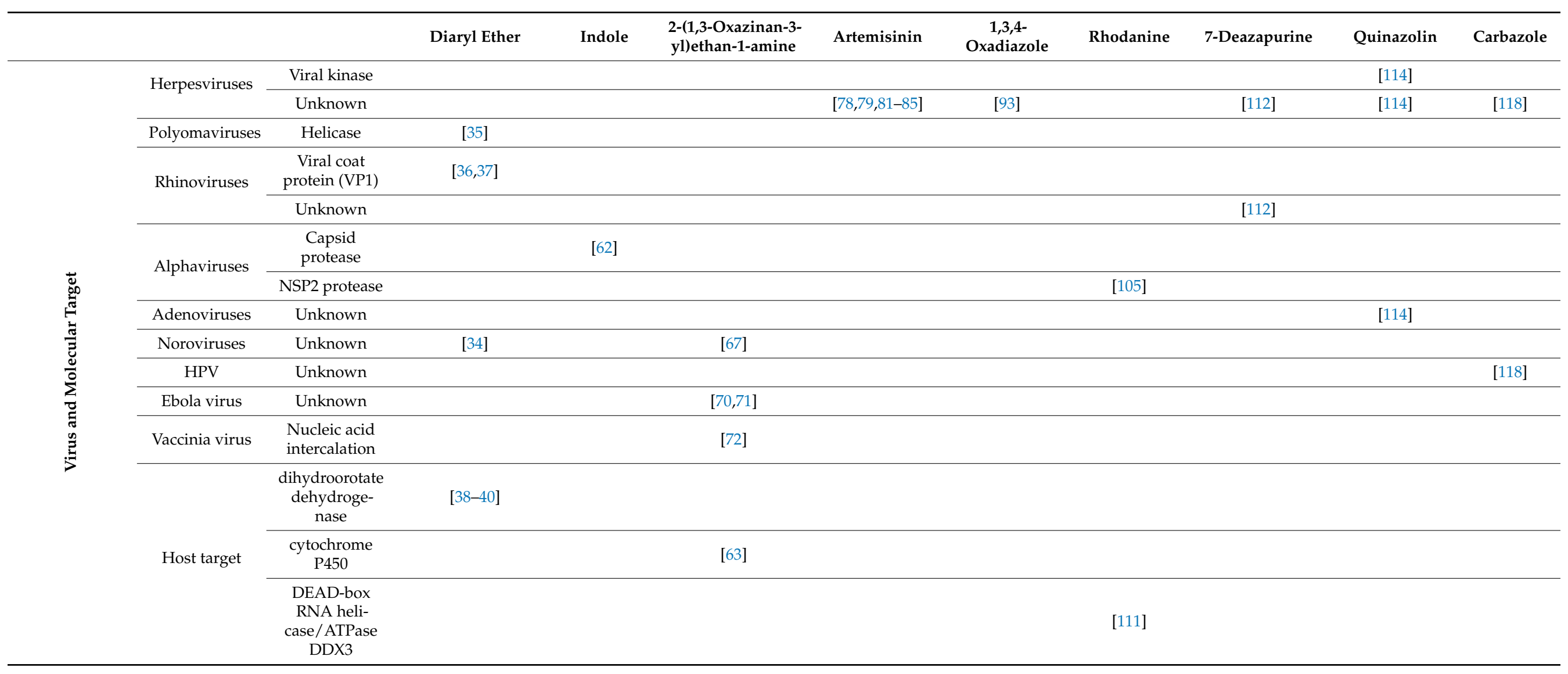


Funding: This research was funded by the Poland National Science Center, grant number UMO2018/29/B/NZ6/02622. This work was supported by a statutory activity subsidy from the Polish Ministry of Science and Higher Education for the Faculty of Chemistry of Wroclaw University of Science and Technology.

Institutional Review Board Statement: Not applicable.

Informed Consent Statement: Not applicable.

Data Availability Statement: No new data were created or analyzed in this study. Data sharing is not applicable to this article.

Conflicts of Interest: The authors declare no conflict of interest.

\section{References}

1. Evans, B.E.; Rittle, K.E.; Bock, M.G.; Dipardo, R.M.; Freidinger, R.M.; Whitter, W.L.; Lundell, G.F.; Veber, D.F.; Anderson, P.S.; Chang, R.S.L.; et al. Methods for Drug Discovery: Development of Potent, Selective, Orally Effective Cholecystokinin Antagonistst. J. Med. Chem. 1988, 31, 2235-2246. [CrossRef]

2. Bolz, S.N.; Adasme, M.F.; Schroeder, M. Toward an Understanding of Pan-Assay Interference Compounds and Promiscuity: A Structural Perspective on Binding Modes. J. Chem. Inf. Model. 2021, 61, 2248-2262. [CrossRef]

3. Baell, J.B.; Nissink, J.W.M. Seven Year Itch: Pan-Assay Interference Compounds (PAINS) in 2017-Utility and Limitations. ACS Chem. Biol. 2017, 13, 36-44. [CrossRef]

4. Lagorce, D.; Oliveira, N.; Miteva, M.A.; Villoutreix, B.O. Pan-assay interference compounds (PAINS) that may not be too painful for chemical biology projects. Drug Discov. Today 2017, 22, 1131-1133. [CrossRef]

5. Jasial, S.; Hu, Y.; Bajorath, J. How Frequently Are Pan-Assay Interference Compounds Active? Large-Scale Analysis of Screening Data Reveals Diverse Activity Profiles, Low Global Hit Frequency, and Many Consistently Inactive Compounds. J. Med. Chem. 2017, 60, 3879-3886. [CrossRef]

6. Pouliot, M.; Jeanmart, S. Pan Assay Interference Compounds (PAINS) and Other Promiscuous Compounds in Antifungal Research. J. Med. Chem. 2015, 59, 497-503. [CrossRef]

7. Baell, J.B.; Holloway, G.A. New Substructure Filters for Removal of Pan Assay Interference Compounds (PAINS) from Screening Libraries and for Their Exclusion in Bioassays. J. Med. Chem. 2010, 53, 2719-2740. [CrossRef]

8. Baell, J.B. Observations on screening-based research and some concerning trends in the literature. Future Med. Chem. 2010, 2, 1529-1546. [CrossRef]

9. Gupta, N.; Wish, J.B. Hypoxia-Inducible Factor Prolyl Hydroxylase Inhibitors: A Potential New Treatment for Anemia in Patients With CKD. Am. J. Kidney Dis. 2017, 69, 815-826. [CrossRef]

10. Pan, Z.; Scheerens, H.; Li, S.-J.; Schultz, B.E.; Sprengeler, P.A.; Burrill, L.C.; Mendonca, R.V.; Sweeney, M.D.; Scott, K.C.K.; Grothaus, P.G.; et al. Discovery of Selective Irreversible Inhibitors for Bruton's Tyrosine Kinase. ChemMedChem 2007, 2, 58-61. [CrossRef]

11. Llovet, J.M.; Ricci, S.; Mazzaferro, V.; Hilgard, P.; Gane, E.; Blanc, J.-F.; de Oliveira, A.C.; Santoro, A.; Raoul, J.-L.; Forner, A.; et al. Sorafenib in Advanced Hepatocellular Carcinoma. N. Engl. J. Med. 2008, 359, 378-390. [CrossRef]

12. Bedos-Belval, F.; Rouch, A.; Vanucci-Bacqué, C.; Baltas, M. Diaryl ether derivatives as anticancer agents-A review. Medchemcomm 2012, 3, 1356-1372. [CrossRef]

13. Chen, T.; Xiong, H.; Yang, J.F.; Zhu, X.L.; Qu, R.Y.; Yang, G.F. Diaryl Ether: A Privileged Scaffold for Drug and Agrochemical Discovery. J. Agric. Food Chem. 2020, 68, 9839-9877. [CrossRef]

14. Kudalkar, S.N.; Ullah, I.; Bertoletti, N.; Mandl, H.K.; Cisneros, J.A.; Beloor, J.; Chan, A.H.; Quijano, E.; Saltzman, W.M.; Jorgensen, W.L.; et al. Structural and pharmacological evaluation of a novel non-nucleoside reverse transcriptase inhibitor as a promising long acting nanoformulation for treating HIV. Antivir. Res. 2019, 167, 110-116. [CrossRef]

15. Adams, J.; Merluzzi, V.J. Discovery of Nevirapine, a Nonnucleoside Inhibitor of HIV-1 Reverse Transcriptase. In The Search for Antiviral Drugs; Birkhäuser: Boston, MA, USA, 1993; pp. 45-70.

16. Wang, Y.; Xing, H.; Liao, L.; Wang, Z.; Su, B.; Zhao, Q.; Feng, Y.; Ma, P.; Liu, J.; Wu, J.; et al. The development of drug resistance mutations K103N Y181C and G190A in long term Nevirapine-containing antiviral therapy. AIDS Res. Ther. 2014, 11, 36. [CrossRef]

17. Namasivayam, V.; Vanangamudi, M.; Kramer, V.G.; Kurup, S.; Zhan, P.; Liu, X.; Kongsted, J.; Byrareddy, S.N. The Journey of HIV-1 Non-Nucleoside Reverse Transcriptase Inhibitors (NNRTIs) from Lab to Clinic. J. Med. Chem. 2019, 62, 4851-4883. [CrossRef]

18. Bollini, M.; Domaoal, R.A.; Thakur, V.V.; Gallardo-Macias, R.; Spasov, K.A.; Anderson, K.S.; Jorgensen, W.L. Computationallyguided optimization of a docking hit to yield catechol diethers as potent anti-HIV agents. J. Med. Chem. 2011, 54, 8582-8591. [CrossRef]

19. Frey, K.M.; Bollini, M.; Mislak, A.C.; Cisneros, J.A.; Gallardo-Macias, R.; Jorgensen, W.L.; Anderson, K.S. Crystal structures of HIV-1 reverse transcriptase with picomolar inhibitors reveal key interactions for drug design. J. Am. Chem. Soc. 2012, 134, 19501-19503. [CrossRef] 
20. Frey, K.M.; Puleo, D.E.; Spasov, K.A.; Bollini, M.; Jorgensen, W.L.; Anderson, K.S. Structure-Based Evaluation of Non-nucleoside Inhibitors with Improved Potency and Solubility That Target HIV Reverse Transcriptase Variants. J. Med. Chem. 2015, 58, 2737-2745. [CrossRef]

21. Jorgensen, W.L.; Bollini, M.; Thakur, V.V.; Domaoal, R.A.; Spasov, K.A.; Anderson, K.S. Efficient discovery of potent anti-HIV agents targeting the Tyr181Cys variant of HIV reverse transcriptase. J. Am. Chem. Soc. 2011, 133, 15686-15696. [CrossRef]

22. Qin, B.; Jiang, X.; Lu, H.; Tian, X.; Barbault, F.; Huang, L.; Qian, K.; Chen, C.H.; Huang, R.; Jiang, S.; et al. Diarylaniline derivatives as a distinct class of HIV-1 non-nucleoside reverse transcriptase inhibitors. J. Med. Chem. 2010, 53, 4906-4916. [CrossRef]

23. Sun, L.Q.; Zhu, L.; Qian, K.; Qin, B.; Huang, L.; Chen, C.H.; Lee, K.H.; Xie, L. Design, synthesis, and preclinical evaluations of novel 4-substituted 1,5-diarylanilines as potent HIV-1 non-nucleoside reverse transcriptase inhibitor (NNRTI) drug candidates. J. Med. Chem. 2012, 55, 7219-7229. [CrossRef]

24. Liu, N.; Qin, B.; Sun, L.Q.; Yu, F.; Lu, L.; Jiang, S.; Lee, K.H.; Xie, L. Physicochemical property-driven optimization of diarylaniline compounds as potent HIV-1 non-nucleoside reverse transcriptase inhibitors. Bioorganic Med. Chem. Lett. 2014, 24, 3719-3723. [CrossRef]

25. Liu, N.; Wei, L.; Huang, L.; Yu, F.; Zheng, W.; Qin, B.; Zhu, D.Q.; Morris-Natschke, S.L.; Jiang, S.; Chen, C.H.; et al. Novel HIV-1 Non-nucleoside Reverse Transcriptase Inhibitor Agents: Optimization of Diarylanilines with High Potency against Wild-Type and Rilpivirine-Resistant E138K Mutant Virus. J. Med. Chem. 2016, 59, 3689-3704. [CrossRef]

26. Chong, P.; Sebahar, P.; Youngman, M.; Garrido, D.; Zhang, H.; Stewart, E.L.; Nolte, R.T.; Wang, L.; Ferris, R.G.; Edelstein, M.; et al. Rational design of potent non-nucleoside inhibitors of HIV-1 reverse transcriptase. J. Med. Chem. 2012, 55, 10601-10609. [CrossRef]

27. Ribone, S.R.; Leen, V.; Madrid, M.; Dehaen, W.; Daelemans, D.; Pannecouque, C.; Briñón, M.C. Synthesis, biological evaluation and molecular modeling of 4,6-diarylpyrimidines and diarylbenzenes as novel non-nucleosides HIV-1 reverse transcriptase inhibitors. Eur. J. Med. Chem. 2012, 58, 485-492. [CrossRef]

28. Frączek, T.; Kamiński, R.; Krakowiak, A.; Naessens, E.; Verhasselt, B.; Paneth, P. Diaryl ethers with carboxymethoxyphenacyl motif as potent HIV-1 reverse transcriptase inhibitors with improved solubility. J. Enzyme Inhib. Med. Chem. 2018, 33, 9-16. [CrossRef]

29. Chan, A.H.; Lee, W.G.; Spasov, K.A.; Cisneros, J.A.; Kudalkar, S.N.; Petrova, Z.O.; Buckingham, A.B.; Anderson, K.S.; Jorgensen, W.L. Covalent inhibitors for eradication of drug-resistant HIV-1 reverse transcriptase: From design to protein crystallography. Proc. Natl. Acad. Sci. USA 2017, 114, 9725-9730. [CrossRef]

30. Talele, T.T.; Arora, P.; Kulkarni, S.S.; Patel, M.R.; Singh, S.; Chudayeu, M.; Kaushik-Basu, N. Structure-based virtual screening, synthesis and SAR of novel inhibitors of hepatitis C virus NS5B polymerase. Bioorganic Med. Chem. 2010, 18, 4630-4638. [CrossRef]

31. Stammers, T.A.; Coulombe, R.; Duplessis, M.; Fazal, G.; Gagnon, A.; Garneau, M.; Goulet, S.; Jakalian, A.; Laplante, S.; Rancourt, J.; et al. Anthranilic acid-based Thumb Pocket 2 HCV NS5B polymerase inhibitors with sub-micromolar potency in the cell-based replicon assay. Bioorganic Med. Chem. Lett. 2013, 23, 6879-6885. [CrossRef]

32. Hucke, O.; Coulombe, R.; Bonneau, P.; Bertrand-Laperle, M.; Brochu, C.; Gillard, J.; Joly, M.A.; Landry, S.; Lepage, O.; LlinàsBrunet, M.; et al. Molecular dynamics simulations and structure-based rational design lead to allosteric HCV NS5B polymerase thumb pocket 2 inhibitor with picomolar cellular replicon potency. J. Med. Chem. 2014, 57, 1932-1943. [CrossRef]

33. Aravapalli, S.; Lai, H.; Teramoto, T.; Alliston, K.R.; Lushington, G.H.; Ferguson, E.L.; Padmanabhan, R.; Groutas, W.C. Inhibitors of Dengue virus and West Nile virus proteases based on the aminobenzamide scaffold. Bioorganic Med. Chem. 2012, 20, 4140-4148. [CrossRef]

34. Dou, D.; Mandadapu, S.R.; Alliston, K.R.; Kim, Y.; Chang, K.O.; Groutas, W.C. Design and synthesis of inhibitors of noroviruses by scaffold hopping. Bioorganic Med. Chem. 2011, 19, 5749-5755. [CrossRef]

35. Bonafoux, D.; Nanthakumar, S.; Bandarage, U.K.; Memmott, C.; Lowe, D.; Aronov, A.M.; Bhisetti, G.R.; Bonanno, K.C.; Coll, J.; Leeman, J.; et al. Fragment-Based Discovery of Dual JC Virus and BK Virus Helicase Inhibitors. J. Med. Chem. 2016, 59, 7138-7151. [CrossRef]

36. Pevear, D.C.; Tull, T.M.; Seipel, M.E.; Groarke, J.M. Activity of pleconaril against enteroviruses. Antimicrob. Agents Chemother. 1999, 43, 2109-2115. [CrossRef]

37. Kim, J.; Jung, Y.K.; Kim, C.; Shin, J.S.; Scheers, E.; Lee, J.Y.; Han, S.B.; Lee, C.K.; Neyts, J.; Ha, J.D.; et al. A Novel Series of Highly Potent Small Molecule Inhibitors of Rhinovirus Replication. J. Med. Chem. 2017, 60, 5472-5492. [CrossRef]

38. Xiong, R.; Zhang, L.; Li, S.; Sun, Y.; Ding, M.; Wang, Y.; Zhao, Y.; Wu, Y.; Shang, W.; Jiang, X.; et al. Novel and potent inhibitors targeting DHODH are broad-spectrum antivirals against RNA viruses including newly-emerged coronavirus SARS-CoV-2. Protein Cell 2020, 11, 723-739. [CrossRef]

39. Das, P.; Deng, X.; Zhang, L.; Roth, M.G.; Fontoura, B.M.A.; Phillips, M.A.; De Brabander, J.K. SAR-based optimization of a 4-quinoline carboxylic acid analogue with potent antiviral activity. ACS Med. Chem. Lett. 2013, 4, 517-521. [CrossRef]

40. Yang, Y.; Cao, L.; Gao, H.; Wu, Y.; Wang, Y.; Fang, F.; Lan, T.; Lou, Z.; Rao, Y. Discovery, Optimization, and Target Identification of Novel Potent Broad-Spectrum Antiviral Inhibitors. J. Med. Chem. 2019, 62, 4056-4073. [CrossRef]

41. Zhang, M.Z.; Chen, Q.; Yang, G.F. A review on recent developments of indole-containing antiviral agents. Eur. J. Med. Chem. 2015, 89, 421-441. [CrossRef]

42. Kumari, A.; Singh, R.K. Medicinal chemistry of indole derivatives: Current to future therapeutic prospectives. Bioorg. Chem. 2019, 89, 103021. [CrossRef] 
43. Dorababu, A. Indole-a promising pharmacophore in recent antiviral drug discovery. RSC Med. Chem. 2020, 11, 1335-1353. [CrossRef]

44. Leneva, I.A.; Russell, R.J.; Boriskin, Y.S.; Hay, A.J. Characteristics of arbidol-resistant mutants of influenza virus: Implications for the mechanism of anti-influenza action of arbidol. Antivir. Res. 2009, 81, 132-140. [CrossRef]

45. Paintsil, E.; Cheng, Y.C. Antiviral Agents. In Encyclopedia of Microbiology; Elsevier Inc.: Amsterdam, The Netherlands, 2009; pp. 223-257.

46. Lawitz, E.; Gane, E.; Pearlman, B.; Tam, E.; Ghesquiere, W.; Guyader, D.; Alric, L.; Bronowicki, J.P.; Lester, L.; Sievert, W.; et al. Efficacy and safety of 12 weeks versus 18 weeks of treatment with grazoprevir (MK-5172) and elbasvir (MK-8742) with or without ribavirin for hepatitis $C$ virus genotype 1 infection in previously untreated patients with cirrhosis and patients with previous null response with or without cirrhosis (C-WORTHY): A randomised, open-label phase 2 trial. Lancet 2015, 385, $1075-1086$.

47. Morse, G.D.; Reichman, R.C.; Fischl, M.A.; Para, M.; Leedom, J.; Powderly, W.; Demeter, L.M.; Resnick, L.; Bassiakos, Y.; Timpone, J.; et al. Concentration-targeted phase I trials of atevirdine mesylate in patients with HIV infection: Dosage requirements and pharmacokinetic studies. Antivir. Res. 2000, 45, 47-58. [CrossRef]

48. Erhardt, A.; Deterding, K.; Benhamou, Y.; Reiser, M.; Forns, X.; Pol, S.; Calleja, J.L.; Ross, S.; Spangenberg, H.C.; Garcia-Samaniego, J.; et al. Safety, pharmacokinetics and antiviral effect of BILB 1941, a novel hepatitis C virus RNA poylmerase inhibitor, after 5 days oral treatment. Antivir. Ther. 2009, 14, 23-32.

49. Ahmed, A.M.; Doheim, M.F.; Mattar, O.M.; Sherif, N.A.; Truong, D.H.; Hoa, P.T.L.; Hirayama, K.; Huy, N.T. Beclabuvir in combination with asunaprevir and daclatasvir for hepatitis $\mathrm{C}$ virus genotype 1 infection: A systematic review and meta-analysis. J. Med. Virol. 2018, 90, 907-918. [CrossRef]

50. Shin, Y.H.; Park, C.M.; Kim, H.G.; Kim, D.E.; Choi, M.S.; Kim, J.A.; Choi, B.S.; Yoon, C.H. Identification of Aristolactam Derivatives That Act as Inhibitors of Human Immunodeficiency Virus Type 1 Infection and Replication by Targeting Tat-Mediated Viral Transcription. Virol. Sin. 2021, 36, 254-263. [CrossRef] [PubMed]

51. Massari, S.; Daelemans, D.; Barreca, M.L.; Knezevich, A.; Sabatini, S.; Cecchetti, V.; Marcello, A.; Pannecouque, C.; Tabarrini, O. A 1,8-Naphthyridone Derivative Targets the HIV-1 Tat-Mediated Transcription and Potently Inhibits the HIV-1 Replication. J. Med. Chem. 2009, 53, 641-648. [CrossRef]

52. Guendel, I.; Iordanskiy, S.; Van Duyne, R.; Kehn-Hall, K.; Saifuddin, M.; Das, R.; Jaworski, E.; Sampey, G.C.; Senina, S.; Shultz, L.; et al. Novel Neuroprotective GSK-3 Inhibitor Restricts Tat-Mediated HIV-1 Replication. J. Virol. 2014, 88, 1189-1208. [CrossRef]

53. Tabarrini, O.; Massari, S.; Sancineto, L.; Daelemans, D.; Sabatini, S.; Manfroni, G.; Cecchetti, V.; Pannecouque, C. Structural Investigation of the Naphthyridone Scaffold: Identification of a 1,6-Naphthyridone Derivative with Potent and Selective Anti-HIV Activity. ChemMedChem 2011, 6, 1249-1257. [CrossRef] [PubMed]

54. Cihan-Üstündağ, G.; Zopun, M.; Vanderlinden, E.; Ozkirimli, E.; Persoons, L.; Çapan, G.; Naesens, L. Superior inhibition of influenza virus hemagglutinin-mediated fusion by indole-substituted spirothiazolidinones. Bioorganic Med. Chem. 2020, 28, 115130. [CrossRef] [PubMed]

55. Morphy, R.; Rankovic, Z. Designed Multiple Ligands. An Emerging Drug Discovery Paradigm. J. Med. Chem. 2005, 48, 6523-6543. [CrossRef]

56. Morphy, R.; Rankovic, Z. The Physicochemical Challenges of Designing Multiple Ligands. J. Med. Chem. 2006, 49, 4961-4970. [CrossRef]

57. Zhan, P.; Liu, X. Designed Multiple Ligands: An Emerging Anti-HIV Drug Discovery Paradigm. Curr. Pharm. Des. 2009, 15. [CrossRef] [PubMed]

58. Zhan, P.; Liu, X. Rationally Designed Multitarget Anti-HIV Agents. Curr. Med. Chem. 2013, 20, 1743-1758. [CrossRef] [PubMed]

59. Sancineto, L.; Iraci, N.; Barreca, M.L.; Massari, S.; Manfroni, G.; Corazza, G.; Cecchetti, V.; Marcello, A.; Daelemans, D.; Pannecouque, C.; et al. Exploiting the anti-HIV 6-desfluoroquinolones to design multiple ligands. Bioorg. Med. Chem. 2014, 22, 4658-4666. [CrossRef]

60. Wang, Z.; Bennett, E.M.; Wilson, D.J.; Salomon, C.; Vince, R. Rationally Designed Dual Inhibitors of HIV Reverse Transcriptase and Integrase. J. Med. Chem. 2007, 50, 3416-3419. [CrossRef] [PubMed]

61. Wu, G.; Yu, G.; Yu, Y.; Yang, S.; Duan, Z.; Wang, W.; Liu, Y.; Yu, R.; Li, J.; Zhu, T.; et al. Chemoreactive-Inspired Discovery of Influenza A Virus Dual Inhibitor to Block Hemagglutinin-Mediated Adsorption and Membrane Fusion. J. Med. Chem. 2020, 63, 6924-6940. [CrossRef]

62. Fatma, B.; Kumar, R.; Singh, V.A.; Nehul, S.; Sharma, R.; Kesari, P.; Kuhn, R.J.; Tomar, S. Alphavirus capsid protease inhibitors as potential antiviral agents for Chikungunya infection. Antivir. Res. 2020, 179, 104808. [CrossRef]

63. Xu, L.; Liu, H.; Hong, A.; Vivian, R.; Murray, B.P.; Callebaut, C.; Choi, Y.C.; Lee, M.S.; Chau, J.; Tsai, L.K.; et al. Structure-activity relationships of diamine inhibitors of cytochrome P450 (CYP) 3A as novel pharmacoenhancers. Part II: P2/P3 region and discovery of cobicistat (GS-9350). Bioorg. Med. Chem. Lett. 2014, 24, 995-999. [CrossRef]

64. Yang, J.; Chen, W.; Kang, D.; Lu, X.; Li, X.; Liu, Z.; Huang, B.; Daelemans, D.; Pannecouque, C.; De Clercq, E.; et al. Design, synthesis and anti-HIV evaluation of novel diarylpyridine derivatives targeting the entrance channel of NNRTI binding pocket. Eur. J. Med. Chem. 2016, 109, 294-304. [CrossRef]

65. Han, Z.; Liang, X.; Wang, Y.; Qing, J.; Cao, L.; Shang, L.; Yin, Z. The discovery of indole derivatives as novel hepatitis C virus inhibitors. Eur. J. Med. Chem. 2016, 116, 147-155. [CrossRef] 
66. Leal, E.S.; Adler, N.S.; Fernández, G.A.; Gebhard, L.G.; Battini, L.; Aucar, M.G.; Videla, M.; Monge, M.E.; Hernández de los Ríos, A.; Acosta Dávila, J.A.; et al. De novo design approaches targeting an envelope protein pocket to identify small molecules against dengue virus. Eur. J. Med. Chem. 2019, 182, 111628. [CrossRef] [PubMed]

67. Dou, D.; Tiew, K.C.; Mandadapu, S.R.; Gunnam, M.R.; Alliston, K.R.; Kim, Y.; Chang, K.O.; Groutas, W.C. Potent norovirus inhibitors based on the acyclic sulfamide scaffold. Bioorganic Med. Chem. 2012, 20, 2111-2118. [CrossRef] [PubMed]

68. Liu, S.; Wang, W.; Jiang, L.; Wan, S.; Zhang, L.; Yu, R.; Jiang, T. 2-Pyridinyl-4(3H)-Quinazolinone: A Scaffold for Anti-influenza A Virus Compounds. Chem. Biol. Drug Des. 2015, 86, 1221-1225. [CrossRef]

69. Li, H.; Chen, L.; Li, S.; Liao, Y.; Wang, L.; Liu, Z.; Liu, S.; Song, G. Incorporation of privileged structures into 3-O- $\beta$-chacotriosyl ursolic acid can enhance inhibiting the entry of the H5N1 virus. Bioorganic Med. Chem. Lett. 2019, 29, 2675-2680. [CrossRef] [PubMed]

70. Opsenica, I.; Burnett, J.C.; Gussio, R.; Opsenica, D.; Todorović, N.; Lanteri, C.A.; Sciotti, R.J.; Gettayacamin, M.; Basilico, N.; Taramelli, D.; et al. A chemotype that inhibits three unrelated pathogenic targets: The botulinum neurotoxin serotype a light chain, P. falciparum malaria, and the Ebola filovirus. J. Med. Chem. 2011, 54, 1157-1169. [CrossRef]

71. Selaković, Ž.; Tran, J.P.; Kota, K.P.; Lazić, M.; Retterer, C.; Besh, R.; Panchal, R.G.; Soloveva, V.; Sean, V.A.; Jay, W.B.; et al. Second generation of diazachrysenes: Protection of Ebola virus infected mice and mechanism of action. Eur. J. Med. Chem. 2019, 162, 32-50. [CrossRef]

72. Klimenko, K.; Lyakhov, S.; Shibinskaya, M.; Karpenko, A.; Marcou, G.; Horvath, D.; Zenkova, M.; Goncharova, E.; Amirkhanov, R.; Krysko, A.; et al. Virtual screening, synthesis and biological evaluation of DNA intercalating antiviral agents. Bioorganic Med. Chem. Lett. 2017, 27, 3915-3919. [CrossRef]

73. Su, X.Z.; Miller, L.H. The discovery of artemisinin and the Nobel Prize in Physiology or Medicine. Sci. China Life Sci. 2015, 58, 1175-1179. [CrossRef]

74. Efferth, T.; Romero, M.R.; Wolf, D.G.; Stamminger, T.; Marin, J.J.G.; Marschall, M. The antiviral activities of artemisinin and artesunate. Clin. Infect. Dis. 2008, 47, 804-811. [CrossRef]

75. Efferth, T. Beyond malaria: The inhibition of viruses by artemisinin-type compounds. Biotechnol. Adv. 2018, 36, 1730-1737. [CrossRef] [PubMed]

76. Jana, S.; Iram, S.; Thomas, J.; Hayat, M.Q.; Pannecouque, C.; Dehaen, W. Application of the triazolization reaction to afford dihydroartemisinin derivatives with anti-HIV activity. Molecules 2017, 22, 303. [CrossRef]

77. Wang, X.; Zheng, B.; Ashraf, U.; Zhang, H.; Cao, C.; Li, Q.; Chen, Z.; Imran, M.; Chen, H.; Cao, S.; et al. Artemisinin inhibits the replication of flaviviruses by promoting the type I interferon production. Antivir. Res. 2020, 179, 104810. [CrossRef] [PubMed]

78. Efferth, T.; Marschall, M.; Wang, X.; Huong, S.M.; Hauber, I.; Olbrich, A.; Kronschnabl, M.; Stamminger, T.; Huang, E.S. Antiviral activity of artesunate towards wild-type, recombinant, and ganciclovir-resistant human cytomegaloviruses. J. Mol. Med. 2002, 80, 233-242. [CrossRef] [PubMed]

79. Kaptein, S.J.F.; Efferth, T.; Leis, M.; Rechter, S.; Auerochs, S.; Kalmer, M.; Bruggeman, C.A.; Vink, C.; Stamminger, T.; Marschall, M. The anti-malaria drug artesunate inhibits replication of cytomegalovirus in vitro and in vivo. Antivir. Res. 2006, 69, 60-69. [CrossRef]

80. Chou, S.; Marousek, G.; Auerochs, S.; Stamminger, T.; Milbradt, J.; Marschall, M. The unique antiviral activity of artesunate is broadly effective against human cytomegaloviruses including therapy-resistant mutants. Antivir. Res. 2011, 92, 364-368. [CrossRef]

81. He, R.; Mott, B.T.; Rosenthal, A.S.; Genna, D.T.; Posner, G.H.; Arav-Boger, R. An artemisinin-derived dimer has highly potent anti-cytomegalovirus (CMV) and anti-cancer activities. PLoS ONE 2011, 6, e24334. [CrossRef]

82. Mott, B.T.; He, R.; Chen, X.; Fox, J.M.; Civin, C.I.; Arav-Boger, R.; Posner, G.H. Artemisinin-derived dimer phosphate esters as potent anti-cytomegalovirus (anti-CMV) and anti-cancer agents: A structure-activity study. Bioorganic Med. Chem. 2013, 21, 3702-3707. [CrossRef]

83. He, R.; Forman, M.; Mott, B.T.; Venkatadri, R.; Posner, G.H.; Arav-Boger, R. Unique and highly selective anticytomegalovirus activities of artemisinin-derived dimer diphenyl phosphate stem from combination of dimer unit and a diphenyl phosphate moiety. Antimicrob. Agents Chemother. 2013, 57, 4208-4214. [CrossRef]

84. Reiter, C.; Fröhlich, T.; Gruber, L.; Hutterer, C.; Marschall, M.; Voigtländer, C.; Friedrich, O.; Kappes, B.; Efferth, T.; Tsogoeva, S.B. Highly potent artemisinin-derived dimers and trimers: Synthesis and evaluation of their antimalarial, antileukemia and antiviral activities. Bioorganic Med. Chem. 2015, 23, 5452-5458. [CrossRef]

85. Wild, M.; Hahn, F.; Grau, B.; Herrmann, L.; Niesar, A.; Schütz, M.; Lorion, M.M.; Ackermann, L.; Tsogoeva, S.B.; Marschall, M. The artemisinin-derived autofluorescent compound bg95 exerts strong anticytomegaloviral activity based on a mitochondrial targeting mechanism. Int. J. Mol. Sci. 2020, 21, 5578. [CrossRef] [PubMed]

86. Blazquez, A.G.; Fernandez-Dolon, M.; Sanchez-Vicente, L.; Maestre, A.D.; Gomez-San Miguel, A.B.; Alvarez, M.; Serrano, M.A.; Jansen, H.; Efferth, T.; Marin, J.J.G.; et al. Novel artemisinin derivatives with potential usefulness against liver/colon cancer and viral hepatitis. Bioorganic Med. Chem. 2013, 21, 4432-4441. [CrossRef] [PubMed]

87. Yi, M.K.; Villanueva, R.A.; Thomas, D.L.; Wakita, T.; Lemon, S.M. Production of infectious genotype 1a hepatitis C virus (Hutchinson strain) in cultured human hepatoma cells. Proc. Natl. Acad. Sci. USA 2006, 103, 2310-2315. [CrossRef] [PubMed]

88. Obeid, S.; Alen, J.; Nguyen, V.H.; Pham, V.C.; Meuleman, P.; Pannecouque, C.; Le, T.N.; Neyts, J.; Dehaen, W.; Paeshuyse, J. Artemisinin analogues as potent inhibitors of in vitro hepatitis C virus replication. PLoS ONE 2013, 8, e81783. [CrossRef] 
89. Li, Z.; Zhan, P.; Liu, X. 1,3,4-Oxadiazole: A Privileged Structure in Antiviral Agents. Mini-Rev. Med. Chem. 2011, 11, 1130-1142. [CrossRef]

90. Salahuddin; Mazumder, A.; Yar, M.S.; Mazumder, R.; Chakraborthy, G.S.; Ahsan, M.J.; Rahman, M.U. Updates on synthesis and biological activities of 1,3,4-oxadiazole: A review. Synth. Commun. 2017, 47, 1805-1847. [CrossRef]

91. Shah, P.; Naik, D.; Jariwala, N.; Bhadane, D.; Kumar, S.; Kulkarni, S.; Bhutani, K.K.; Singh, I.P. Synthesis of C-2 and C-3 substituted quinolines and their evaluation as anti-HIV-1 agents. Bioorg. Chem. 2018, 80, 591-601. [CrossRef]

92. Benmansour, F.; Eydoux, C.; Querat, G.; De Lamballerie, X.; Canard, B.; Alvarez, K.; Guillemot, J.C.; Barral, K. Novel 2-phenyl5-[(E)-2-(thiophen-2-yl)ethenyl]-1,3,4-oxadiazole and 3-phenyl-5-[(E)-2-(thiophen-2-yl)ethenyl]-1,2,4-oxadiazole derivatives as dengue virus inhibitors targeting NS5 polymerase. Eur. J. Med. Chem. 2016, 109, 146-156. [CrossRef]

93. El Mansouri, A.E.; Maatallah, M.; Ait Benhassou, H.; Moumen, A.; Mehdi, A.; Snoeck, R.; Andrei, G.; Zahouily, M.; Lazrek, H.B. Design, synthesis, chemical characterization, biological evaluation, and docking study of new 1,3,4-oxadiazole homonucleoside analogs. Nucleosides Nucleotides Nucleic Acids 2020, 39, 1088-1107. [CrossRef] [PubMed]

94. Tomašić, T.; Peterlin Mašič, L. Rhodanine as a scaffold in drug discovery: A critical review of its biological activities and mechanisms of target modulation. Expert Opin. Drug Discov. 2012, 7, 549-560. [CrossRef] [PubMed]

95. Rajamaki, S.; Innitzer, A.; Falciani, C.; Tintori, C.; Christ, F.; Witvrouw, M.; Debyser, Z.; Massa, S.; Botta, M. Exploration of novel thiobarbituric acid-, rhodanine- and thiohydantoin-based HIV-1 integrase inhibitors. Bioorganic Med. Chem. Lett. 2009, 19, 3615-3618. [CrossRef] [PubMed]

96. Rinaldi, M.; Tintori, C.; Franchi, L.; Vignaroli, G.; Innitzer, A.; Massa, S.; Esté, J.A.; Gonzalo, E.; Christ, F.; Debyser, Z.; et al. A Versatile and Practical Synthesis toward the Development of Novel HIV-1 Integrase Inhibitors. ChemMedChem 2011, 6, 343-352. [CrossRef]

97. Sancineto, L.; Iraci, N.; Tabarrini, O.; Santi, C. NCp7: Targeting a multitasking protein for next-generation anti-HIV drug development part 1: Covalent inhibitors. Drug Discov. Today 2018, 23, 260-271. [CrossRef] [PubMed]

98. Mori, M.; Kovalenko, L.; Lyonnais, S.; Antaki, D.; Torbett, B.E.; Botta, M.; Mirambeau, G.; Mély, Y. Nucleocapsid Protein: A Desirable Target for Future Therapies Against HIV-1. Curr. Top. Microbiol. Immunol. 2015, 389, $53-92$.

99. Goudreau, N.; Hucke, O.; Faucher, A.M.; Grand-Maître, C.; Lepage, O.; Bonneau, P.R.; Mason, S.W.; Titolo, S. Discovery and Structural Characterization of a New Inhibitor Series of HIV-1 Nucleocapsid Function: NMR Solution Structure Determination of a Ternary Complex Involving a 2:1 Inhibitor/NC Stoichiometry. J. Mol. Biol. 2013, 425, 1982-1998. [CrossRef]

100. Nitsche, C.; Schreier, V.N.; Behnam, M.A.M.; Kumar, A.; Bartenschlager, R.; Klein, C.D. Thiazolidinone-peptide hybrids as dengue virus protease inhibitors with antiviral activity in cell culture. J. Med. Chem. 2013, 56, 8389-8403. [CrossRef]

101. Stahla-Beek, H.J.; April, D.G.; Saeedi, B.J.; Hannah, A.M.; Keenan, S.M.; Geiss, B.J. Identification of a Novel Antiviral Inhibitor of the Flavivirus Guanylyltransferase Enzyme. J. Virol. 2012, 86, 8730-8739. [CrossRef]

102. Quek, J.P.; Liu, S.; Zhang, Z.; Li, Y.; Ng, E.Y.; Loh, Y.R.; Hung, A.W.; Luo, D.; Kang, C.B. Identification and structural characterization of small molecule fragments targeting Zika virus NS2B-NS3 protease. Antivir. Res. 2020, 175, 104707. [CrossRef]

103. Murray, C.W.; Rees, D.C. The rise of fragment-based drug discovery. Nat. Chem. 2009, 1, 187-192. [CrossRef] [PubMed]

104. Erlanson, D.A.; McDowell, R.S.; O’Brien, T. Fragment-Based Drug Discovery. J. Med. Chem. 2004, 47, 3463-3482. [CrossRef] [PubMed]

105. Jadav, S.S.; Sinha, B.N.; Hilgenfeld, R.; Pastorino, B.; De Lamballerie, X.; Jayaprakash, V. Thiazolidone derivatives as inhibitors of chikungunya virus. Eur. J. Med. Chem. 2015, 89, 172-178. [CrossRef] [PubMed]

106. Wolf, M.C.; Freiberg, A.N.; Zhang, T.; Akyol-Ataman, Z.; Grock, A.; Hong, P.W.; Li, J.; Watson, N.F.; Fang, A.Q.; Aguilar, H.C.; et al. A broad-spectrum antiviral targeting entry of enveloped viruses. Proc. Natl. Acad. Sci. USA 2010, 107, 3157-3162. [CrossRef]

107. Vigant, F.; Lee, J.; Hollmann, A.; Tanner, L.B.; Akyol Ataman, Z.; Yun, T.; Shui, G.; Aguilar, H.C.; Zhang, D.; Meriwether, D.; et al A Mechanistic Paradigm for Broad-Spectrum Antivirals that Target Virus-Cell Fusion. PLoS Pathog. 2013, 9, e1003297. [CrossRef]

108. Hollmann, A.; Castanho, M.A.R.B.; Lee, B.; Santos, N.C. Singlet oxygen effects on lipid membranes: Implications for the mechanism of action of broad-spectrum viral fusion inhibitors. Biochem. J. 2014, 459, 161-170. [CrossRef]

109. Cagno, V.; Tintori, C.; Civra, A.; Cavalli, R.; Tiberi, M.; Botta, L.; Brai, A.; Poli, G.; Tapparel, C.; Lembo, D.; et al. Novel broad spectrum virucidal molecules against enveloped viruses. PLoS ONE 2018, 13, e0208333. [CrossRef]

110. Tintori, C.; Iovenitti, G.; Ceresola, E.R.; Ferrarese, R.; Zamperini, C.; Brai, A.; Poli, G.; Dreassi, E.; Cagno, V.; Lembo, D.; et al. Rhodanine derivatives as potent anti-HIV and anti-HSV microbicides. PLoS ONE 2018, 13, e0198478. [CrossRef]

111. Maga, G.; Falchi, F.; Radi, M.; Botta, L.; Casaluce, G.; Bernardini, M.; Irannejad, H.; Manetti, F.; Garbelli, A.; Samuele, A.; et al. Toward the Discovery of Novel Anti-HIV Drugs. Second-Generation Inhibitors of the Cellular ATPase DDX3 with Improved AntiHIV Activity: Synthesis, Structure-Activity Relationship Analysis, Cytotoxicity Studies, and Target Validation. ChemMedChem 2011, 6, 1371-1389. [CrossRef]

112. Perlíková, P.; Hocek, M. Pyrrolo[2,3-d]pyrimidine (7-deazapurine) as a privileged scaffold in design of antitumor and antiviral nucleosides. Med. Res. Rev. 2017, 37, 1429-1460. [CrossRef]

113. Lin, C.; Yu, J.; Hussain, M.; Zhou, Y.; Duan, A.; Pan, W.; Yuan, J.; Zhang, J. Design, synthesis, and biological evaluation of novel 7-deazapurine nucleoside derivatives as potential anti-dengue virus agents. Antivir. Res. 2018, 149, 95-105. [CrossRef] [PubMed]

114. Alagarsamy, V.; Chitra, K.; Saravanan, G.; Solomon, V.R.; Sulthana, M.T.; Narendhar, B. An overview of quinazolines: Pharmacological significance and recent developments. Eur. J. Med. Chem. 2018, 151, 628-685. [CrossRef] [PubMed] 
115. Modh, R.P.; De Clercq, E.; Pannecouque, C.; Chikhalia, K.H. Design, synthesis, antimicrobial activity and anti-HIV activity evaluation of novel hybrid quinazoline-triazine derivatives. J. Enzym. Inhib. Med. Chem. 2014, 29, 100-108. [CrossRef] [PubMed]

116. Sancineto, L.; Iraci, N.; Massari, S.; Attanasio, V.; Corazza, G.; Barreca, M.L.; Sabatini, S.; Manfroni, G.; Avanzi, N.R.; Cecchetti, V.; et al. Computer-aided design, synthesis and validation of 2-phenylquinazolinone fragments as CDK9 inhibitors with anti-HIV-1 tat-mediated transcription activity. ChemMedChem 2013, 8, 1941-1953. [CrossRef] [PubMed]

117. Rothan, H.A.; Faraj, F.L.; Teoh, T.C.; Yusof, R. Novel Quinazoline derivatives inhibited HCV Serine protease and viral replication in Huh-7 cells. bioRxiv 2019, 671313.

118. Caruso, A.; Ceramella, J.; Iacopetta, D.; Saturnino, C.; Mauro, M.V.; Bruno, R.; Aquaro, S.; Sinicropi, M.S. Carbazole derivatives as antiviral agents: An overview. Molecules 2019, 24, 1912. [CrossRef]

119. Spizzichino, S.; Mattedi, G.; Lauder, K.; Valle, C.; Aouadi, W.; Canard, B.; Decroly, E.; Kaptein, S.J.F.; Neyts, J.; Graham, C.; et al. Design, Synthesis and Discovery of N,N'-Carbazoyl-aryl-urea Inhibitors of Zika NS5 Methyltransferase and Virus Replication. ChemMedChem 2020, 15, 385-390. [CrossRef]

120. Baell, J.; Walters, M.A. Chemistry: Chemical con artists foil drug discovery. Nat. News 2014, 513, 481-483. [CrossRef] [PubMed] 